\title{
ASSESSMENT OF SEISMIC HAZARD AND MICROZONING IN THE PHILIPPINES
}

\author{
Ribelito F. TORREGOSA ${ }^{1}$, Masata SUGITO² and Nobuoto NOJIMA ${ }^{3}$ \\ ${ }^{1}$ Dr. Eng., Engineer, Taiyou Kensetsu Consultant Co. Ltd. \\ (3-1 Koumei-cho, Gifu-shi, Gifu 500-8868, Japan) \\ E-mail:ribtor@taiyou.co.jp \\ ${ }^{2}$ Member of JSCE, Dr. Eng., Professor, River Basin Research Center, (xifu University \\ (1-1 Yanagido, Gifu 501-1193, Japan) \\ E-mail:sugito@cive.gifu-u.ac.jp \\ ${ }^{3}$ Nember of JSCE, Dr. Eng., Assoc. Professor, Dept. of Civil Eng., Gifu University \\ (1-1 Yanagido, Gifu 501-1193, Japan) \\ E-mail:nojima@cive.gifu-u.ac.jp
}

\begin{abstract}
Seismic hazard and microzoning of the Philippines are presented. Seismic hazard analysis of the Philippines on rock-surface level is done to all land areas of the country. The analysis includes both the historical earthquake occurrences and active fault data. Ground motion amplification corrections based on surface geology is determined based on the representative soil softness index of each geology type. The resulting amplification corrections are applied to the rock-surface seismic hazard of the Philippines. A significant increase of seismic hazard by applying the amplification corrections is shown for the city of Manila.
\end{abstract}

Key Words : seismic hazard, hazard-consistent ground motion simulation, soil amplification factor

\section{INTRODUCTION}

The Philippines is located in one of the most seismically active regions of Asia. Many destructive earthquakes have occurred in different parts of the country. The most destructive event was the 1990 Central Luzon earthquake with a surface wave magnitude of $M_{S}=7.6$. The movement of the Philippine Sea plate causes majority of the seismic activities in the country. The Philippine trench which is formed by the subduction of the Philippine Sea plate under the Eurasia plate is one of the major seismic generators in the country. Other major seismic generators are the Philippine fault and Manila trench.

Seismic hazard studies for the Philippines in the past have been done based only on historical earthquakes. Villaraza ${ }^{1)}$ did a seismic hazard analysis of the Philippines and proposed four seismic zones for the Philippines based on the isoseismal map presented by $\mathrm{Su}^{2}$ ). Molas and Yamazaki $^{3)}$ did a seismic hazard analysis of the Philippines based on historical earthquakes that occurred from 1907 to 1990 . In their study, seismic hazard in Baguio City, which was devastated by the 1990 earthquake, is the highest among land areas of the country. They proposed a revision of the seismic source zoning of the Philippines. However, the study did not make use of seismic source zones and seismic hazards from fault sources were not considered. Torregosa, et al. ${ }^{4)}$ analyzed the seismic hazard in the Philippines on rock-surface level. Rock-surface level referred to the stiff ground level with shear wave velocity of $v_{s}=500 \sim 600 \mathrm{~m} / \mathrm{sec}$. The stiff ground was referred to as "free rock-surface". Their purpose of determining the seismic hazard on rock-surface level is that the effect of ground motion amplification due to local soil conditions can be applied by multiplying the correction factors.

The objective of this study is to analyze the seismic hazard of the Philippines, combining the effects of both historical earthquakes and active faults. As a first trial of ground motion amplification corrections for the Philippines, the conversion factor based on surface geology was applied 
to the rock-surface level seismic ground motions

\section{DATABASE FOR SEISMIC HAZ- ARD ANALYSIS AND MODEL- ING OF SOURCE ZONES}

\section{(1) Historical occurrence data}

This information was obtained from Philippine Institute of Volcanology and Seismology (PHIVOLCS). Data for 5969 historical earthquakes ${ }^{5)}$ recorded since 1907 were used in the study. The historical earthquakes with surface wave magnitudes, $M_{S} \geq 5.0$ are shown in Fig. 1. The collected earthquake records were incomplete for $M_{S}<6.0$, therefore, the years of complete records for different magnitude ranges had to be determined. The yearly occurrences of earthquakes from $M_{S}=4.0$ were analyzed. The incompleteness of historical earthquake information can be grouped into three magnitude ranges, $M_{S} \geq 6.0,4.5 \leq M_{S} \leq 5.9$, and $4.0 \leq M_{S} \leq 4.4$. Period with complete records of lower magnitude rarthquakes is too short. In order to maximize the use of the entire historical earthquake occurrence data, corrections ${ }^{6)}$ were made to the quantities of each magnitude since 1907 for which there are no complete records.

Assuming that the occurrence of an earthquake with a given magnitude range $i$ is random and independent of past earthquakes, the occurrence rate $\nu_{i}$ can be calculated as:

$$
\nu_{i}=\frac{n_{i}}{t_{i}}
$$

where $n_{i}$ is the number of earthquakes with magnitude range $i$ and $t_{i}$ is the period of complete observation. The average occurrence rate $\nu_{j k}$ from magnitude ranges $j$ to $k$ can be written as:

$$
\nu_{j k}=\sum_{i=j}^{k} \nu_{i}=\sum_{i=j}^{k} \frac{n_{i}}{t_{i}}
$$

Letting $T$ as the reference period

$$
\nu_{j k}=\frac{1}{T} \sum_{i=j}^{k} n_{i} \frac{T}{t_{i}}
$$

$\frac{T}{t_{i}}$ is the correction factor for different magnitude ranges taking into consideration the reference time period $T$ and the time of complete recording $t_{i}$. Here the reference time period, $T$, is 92 years (from 1907-1998 years). The correction factors are computed as follows:

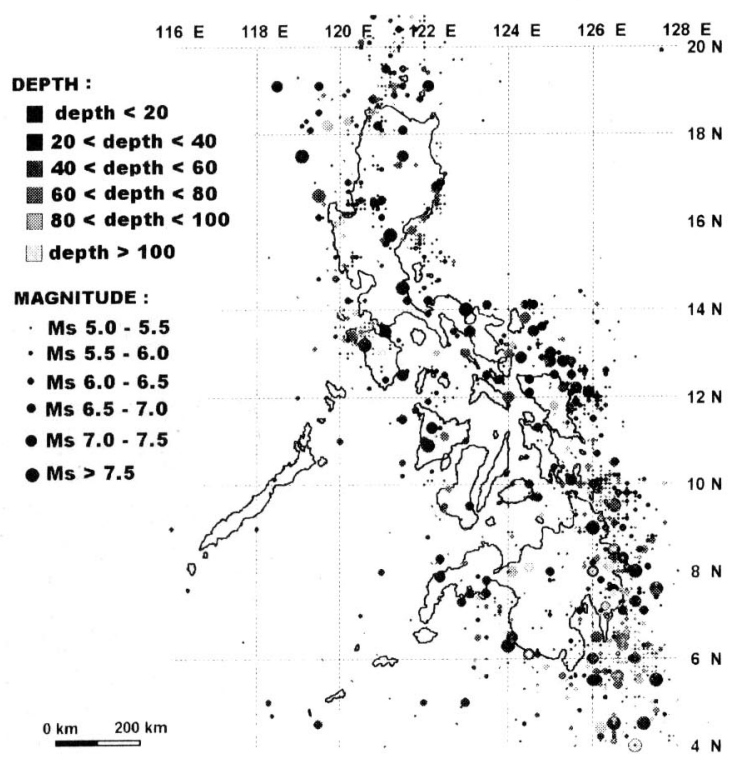

Fig. 1 IIistorical earthquakes

1. For $M_{S} \geq 6.0: \frac{T}{l_{i}}=\frac{92}{92}=1.0$

2. For $4.5 \leq M_{S} \leq 5.9 ; \frac{T}{f_{i}}=\frac{92}{37}=2.48$

3. For $M_{S} \leq 4.4: \frac{T}{l_{i}}=\frac{92}{24}=3.83$

These correction factors are multiplied by the total number of occurrences within the specified magnitude range.

\section{(2) Modeling of seismogenic source zones}

One of the important procedures in seismic hazard analysis is the division of seismic source zones in which seismic activity can be treated as homogenous. Rast and Sacgesser ${ }^{7)}$ demonstrated the effects of varying the seismic source zones. They pointed out that variation in seismic source zoning accounts for as much as half of the difference in the results, whereas the other half is due to different assumptions, such as upper bounds on magnitude and other factors. Seismic source zoning therefore must be done systematically, the seismic characteristic in each individual source zone consequently being homogenous.

To ensure that the designated seismic source zones used in the hazard analysis had homogenous seismic characteristics, the occurrence rates of earthquakes for the entire country were calculated. Spatial moving average was used to determine the occurrence rates of earthquakes at individual points of the country. The occurrence rate at a point was determined by dividing the number of occurrences within $100 \mathrm{~km}$ radius by 


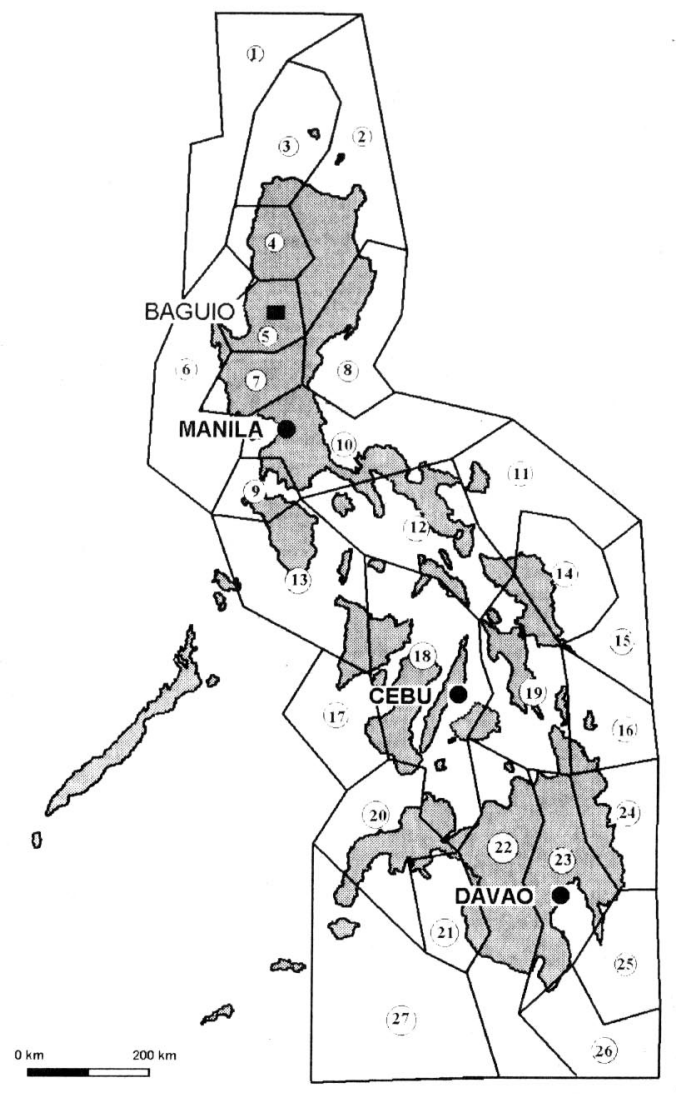

Fig. 2 Seismogenic zones

the area of a circle with a radius of $100 \mathrm{~km}$ to get the average number of occurrences per square $\mathrm{km}$ at the point. The result was divided by the number of years covered by the data to obtain the occurrences per square kilometer per year. The occurrence rates at all points in the country for $M_{S} \geq 4.0$ were calculated using the procedure described above. Polygons were drawn enclosing adjacent areas with nearly uniform occurrence rates. Each polygon was designated as seismogenic zone for which uniform and random occurrences of earthquakes are assumed. A total of 27 seismogenic zones were designated based on the zoning method described earlier. These source zones are shown in Fig. 2. The average focal depth of all the earthquakes inside these zones is $25.1 \mathrm{~km}$.

Linear regression analysis was done to determine the b-value of each seismic source zone. The properties of each zone (i.e., occurrence rate, $b$ value and historical maximum magnitude) are tabulated in Table 1. The historical maximum magnitude within each seismogenic zone was used
Table 1 Seismogenic zone properties $\left(M_{S} \geq 4.0\right)$

\begin{tabular}{|c|c|c|c|}
\hline zone & $\begin{array}{c}\text { occurrence rate } \\
\text { per sq. } \mathbf{~ m} \text {. }\end{array}$ & $\begin{array}{c}\text { b } \\
\text { value }\end{array}$ & $\begin{array}{c}\text { historical max. } \\
\text { magnitude (Ms) }\end{array}$ \\
\hline 1 & $1.46 \mathrm{E}-05$ & 0.940 & 7.3 \\
\hline 2 & $1.49 \mathrm{E}-05$ & 1.056 & 7.2 \\
\hline 3 & $6.60 \mathrm{E}-05$ & 1.571 & 6.9 \\
\hline 4 & $2.94 \mathrm{E}-05$ & 1.458 & 6.5 \\
\hline 5 & $6.40 \mathrm{E}-05$ & 1.431 & 6.6 \\
\hline 6 & $1.33 \mathrm{E}-05$ & 1.093 & 7.7 \\
\hline 7 & $4.17 \mathrm{E}-05$ & 1.215 & 7.8 \\
\hline 8 & $5.96 \mathrm{E}-05$ & 1.792 & 7 \\
\hline 9 & $1.35 \mathrm{E}-04$ & 1.489 & 7.7 \\
\hline 10 & $6.37 \mathrm{E}-06$ & 0.598 & 7.6 \\
\hline 11 & $2.04 \mathrm{E}-05$ & 1.217 & 7.1 \\
\hline 12 & $1.23 \mathrm{E}-05$ & 0.743 & 7.4 \\
\hline 13 & $1.96 \mathrm{E}-05$ & 1.043 & 8.3 \\
\hline 14 & $8.10 \mathrm{E}-05$ & 1.072 & 7.3 \\
\hline 15 & $1.51 \mathrm{E}-05$ & 1.939 & 6 \\
\hline 16 & $1.38 \mathrm{E}-04$ & 1.453 & 7.7 \\
\hline 17 & $1.41 \mathrm{E}-05$ & 1.353 & 6.3 \\
\hline 18 & $6.28 \mathrm{E}-06$ & 1.330 & 6.7 \\
\hline 19 & $3.50 \mathrm{E}-05$ & 1.210 & 7 \\
\hline 20 & $1.17 \mathrm{E}-05$ & 0.888 & 7.3 \\
\hline 21 & $3.36 \mathrm{E}-05$ & 1.074 & 7.9 \\
\hline 22 & $1.26 \mathrm{E}-05$ & 1.130 & 7.3 \\
\hline 23 & $3.46 \mathrm{E}-05$ & 1.429 & 7.4 \\
\hline 24 & $1.04 \mathrm{E}-04$ & 1.274 & 7.7 \\
\hline 25 & $1.23 \mathrm{E}-04$ & 1.301 & 7.3 \\
\hline 26 & $3.24 \mathrm{E}-05$ & 0.880 & 7.9 \\
\hline 27 & $3.33 \mathrm{E}-06$ & 1.111 & 6.5 \\
\hline & & & \\
\hline
\end{tabular}

as the upper bound magnitude during the hazard analysis.

\section{(3) Active fault data}

Active faults of the Philippines are shown in Fig. 3. To incorporate the contributions of active faults into the seismic hazard analysis, parameters such as the expected earthquake magnitudes and annual frequency of expected earthquake magnitudes had to be determined. Due to lack of information on these parameters, fault parameters in other countries were referred. Matsuda ${ }^{8)}$ had determined the maximum expected earthquake magnitude based on fault lengths. The relationship is given in Eq. (4).

$$
\log _{10} L=0.6 M_{J}-2.9
$$

where:

$$
\begin{aligned}
& M_{J}=\text { magnitude in JMA scale } \\
& L=\text { fault length in } \mathrm{km}
\end{aligned}
$$

Seismic hazards from fault sources are presented in three fault rupture length, $\left(L_{F}\right)$, scenarios. These are:

a) scenario $1: L_{F}=L$

b) scenario $2: L_{F}=L / 2$

c) scenario 3: $L_{F}=L / 4$ 
Table 2 Fault types and slip rates ${ }^{8)}$

\begin{tabular}{|c|c|}
\hline Type & slip rate $(\mathrm{m} / 1000$ years $)$ \\
\hline A & $1 \leqq \mathrm{~s}<10$ \\
\hline B & $0.1 \leqq \mathrm{~s}<1$ \\
\hline C & $0.01 \leqq \mathrm{~s}<0.1$ \\
\hline
\end{tabular}

Scenario 1 is characterized by rare large events with very low annual occurrence frequency, scenario 2 for earthquake magnitudes with moderate to low annual occurrence frequency whereas scenario 3 is for many small events with annual occurrence frequencies higher than scenario 2. Magnitudes for partial ruptures were calculated by substituting the rupture lengths to Eq. (4). Incorporating a random earthquake magnitude for each fault is not possible with the present amount of fault data because this will involve the b-value for each active fault. Active faults in the country other than the Philippine trench, Philippine fault and Manila trench have no record of past earthquake events, so this study assumed three possible rupture scenarios to get the expected earthquake magnitude from each fault source. In the analysis, the seismic hazard on each site was calculated by adopting the maximum of the three ground motion intensities from the three scenarios.

Magnitude in Eq. (4) is based on JMA magnitude scale. The empirical relation (Eq. (5)) for converting JMA scale magnitude $\left(M_{J}\right)$ to surface wave magnitude $\left(M_{S}\right)$ proposed by Hayashi and $\mathrm{Abe}^{9)}$ was used. Variations in the conversion were neglected.

$$
M_{S}=1.27 M_{J}-1.83
$$

Annual occurrence frequencies, $\nu_{F}$, were determined by utilizing Matsuda's relationship ${ }^{8)}$ between the earthquake magnitude $\left(M_{J}\right)$ and slip of a single event, $D_{0}(\mathrm{~m})$ given in Eq. (6)

$$
\log _{10} D_{0}=0.6 M_{J}-4.0
$$

Substituting Eq. (4) to Eq. (6) gives the relationship between fault length $\left(L_{F}\right)$ and its slip from a single even, $D_{0}$ given in Eq. (7)

$$
\log _{10} D_{0}=\log _{10} L_{F}-1.0
$$

From the slip rate, $s$ (m per 1000 years) and slip of a single event $D_{0}(\mathrm{~m}), \nu_{F}$ is calculated as:

$$
\nu_{F}=\frac{s}{10^{1.9} L_{F}}
$$

where:

$$
s=\text { fault slip rate (m per } 1000 \text { years) }
$$

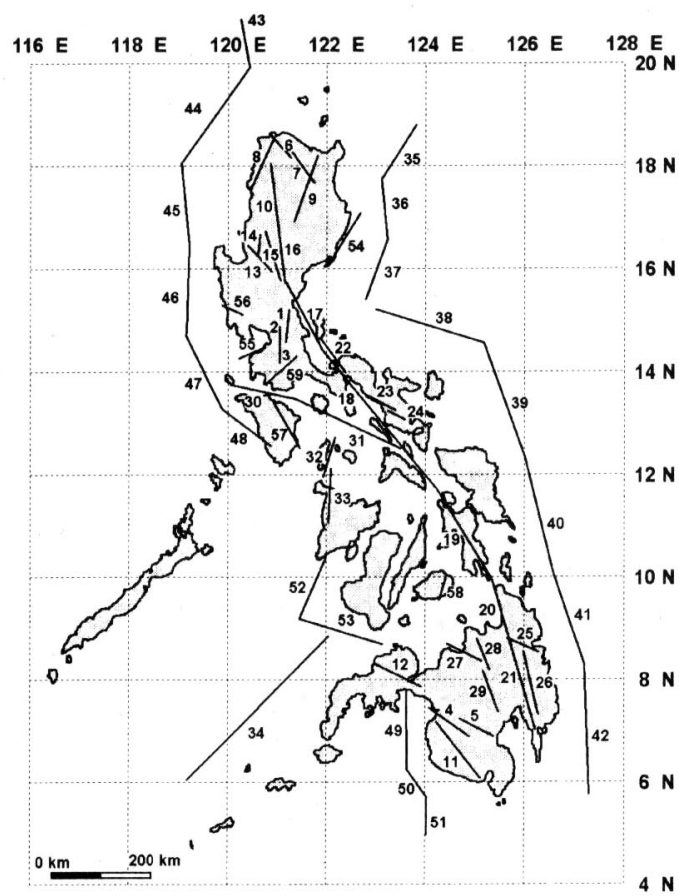

Fig. 3 Philippine active faults ${ }^{10)}$

$L_{F}=$ length of fault rupture $(\mathrm{km})$

Slip rates of the three most active faults of the country were assigned as maximum of Type A (see Table 2) since their actual slip rates exceed that of Type A faults while the rest were assigned within the range of Type A or Type B faults. Fault parameters are given in Table 3.

\section{SEISMIC HAZARD ANALYSIS OF THE PHILIPPINES}

\section{(1) Probabilistic seismic hazard analysis formulation $^{14), 15)}$}

The annual probability that the random earthquake intensity at a site will exceed a value $\gamma$ assuming the Poisson process can be represented by:

$$
p_{0}=1-\exp \left\{-\sum_{k=1}^{n} \nu_{k} q_{k}(\gamma)\right\}
$$

where $n$ is the number of potential earthquake sources in the region of a site, $\nu_{k}$ is the earthquake occurrence rate in the source $k$ with upper and lower boundary magnitudes, $m_{u k}$ and $m_{l k}$, and $q_{k}(\gamma)$ represents the probability that the random earthquake intensity $\Gamma$, will exceed the given intensity $\gamma$ given that an earthquake occurs in the 
Table 3 Philippine active fault parameters used in the hazard analysis

\begin{tabular}{|c|c|c|c|c|c|c|c|c|c|c|}
\hline \multirow{3}{*}{\begin{tabular}{|l} 
\\
No. \\
\end{tabular}} & \multirow[b]{3}{*}{ Fault } & \multirow[b]{3}{*}{ Type $^{\star}$} & \multirow{3}{*}{$\frac{\text { slip rate }^{\otimes}}{\mathrm{mm} / \text { year }}$} & \multirow{3}{*}{$\frac{\text { Length }}{(\mathrm{km})}$} & \multirow{2}{*}{\multicolumn{2}{|c|}{$\begin{array}{c}\text { Scenario 1 } \\
L_{F}=\text { Length } \\
\end{array}$}} & \multirow{2}{*}{\multicolumn{2}{|c|}{$\begin{array}{c}\text { Scenario 2 } \\
L_{F}=\text { Length } / 2 \\
\end{array}$}} & \multirow{2}{*}{\multicolumn{2}{|c|}{$\begin{array}{c}\text { Scenario } 3 \\
L_{F}=\text { Length } / 4\end{array}$}} \\
\hline & & & & & & & & & & \\
\hline & & & & & $M_{S}$ & $\nu_{F}$ & $M_{S}$ & $\nu_{F}$ & $M_{S}$ & $\nu_{F}$ \\
\hline 1 & Marikina fault segment 1 & $\mathrm{~A}$ & $1^{* *}$ & 35.2 & 7.6 & $3.57 \mathrm{E}-04$ & 6.9 & $7.14 \mathrm{E}-04$ & 6.3 & $1.43 \mathrm{E}-03$ \\
\hline 2 & Marikina fault segment 2 & A & $1^{* *}$ & 17.5 & 6.9 & $7.19 \mathrm{E}-04$ & 6.3 & $1.44 \mathrm{E}-0.3$ & 5.7 & $2.88 \mathrm{E}-03$ \\
\hline 3 & Marikina fault segment 3 & $\mathrm{~A}$ & $1^{* *}$ & 22.6 & 7.2 & $5.57 \mathrm{E}-04$ & 6.5 & $1.11 \mathrm{E}-03$ & 5.9 & $2.23 \mathrm{E}-03$ \\
\hline 4 & Cotabato fault segment 1 & $\mathrm{~A}$ & $1^{* *}$ & 43.3 & 7.8 & $2.91 \mathrm{E}-04$ & 7.1 & $5.82 \mathrm{E}-04$ & 6.5 & $1.16 \mathrm{E}-03$ \\
\hline 5 & Cotabato fault segment 2 & $\mathrm{~A}$ & $1^{* *}$ & 54.0 & 8.0 & $2.33 \mathrm{E}-04$ & 7.3 & $4.66 \mathrm{E}-04$ & 6.7 & $9.33 \mathrm{E}-04$ \\
\hline 6 & Abral & $\mathrm{A}$ & $1^{* *}$ & 32.1 & 7.5 & $3.92 \mathrm{E}-04$ & 6.9 & $7.84 \mathrm{E}-04$ & 6.2 & $1.57 \mathrm{E}-03$ \\
\hline 7 & Abra2 & A & $1^{* *}$ & 39.7 & 7.7 & $3.17 \mathrm{E}-04$ & 7.1 & $6.34 \mathrm{E}-04$ & 6.4 & $1.27 \mathrm{E}-03$ \\
\hline 8 & Abra3 & $\mathrm{A}$ & $1^{* *}$ & 64.0 & 8.1 & $1.97 \mathrm{E}-04$ & 7.5 & $3.93 \mathrm{E}-04$ & 6.9 & $7.86 \mathrm{E}-04$ \\
\hline 9 & Abra4 & $\mathrm{A}$ & $1^{* *}$ & 75.9 & 8.3 & $1.66 \mathrm{E}-04$ & 7.7 & $3.32 \mathrm{E}-04$ & 7.0 & $6.64 \mathrm{E}-04$ \\
\hline 10 & Abra5 & A & $1^{* *}$ & 71.9 & 8.2 & $1.75 \mathrm{E}-04$ & 7.6 & $3.50 \mathrm{E}-04$ & 7.0 & $7.00 \mathrm{E}-04$ \\
\hline 11 & Mindanaol & A & $1^{* *}$ & 67.3 & 8.2 & $1.87 \mathrm{E}-04$ & 7.5 & $3.74 \mathrm{E}-04$ & 6.9 & $7.48 \mathrm{E}-04$ \\
\hline 12 & Mindanao2 & $\mathrm{A}$ & $1^{* *}$ & 57.8 & 8.0 & $2.18 \mathrm{E}-04$ & 7.4 & $4.36 \mathrm{E}-04$ & 6.8 & $8.72 \mathrm{E}-04$ \\
\hline 13 & Phil. Fault Luzon 1 & $\mathrm{~A}$ & $8^{*}$ & 38.5 & 7.7 & $3.27 \mathrm{E}-04$ & 7.0 & $6.54 \mathrm{E}-04$ & 6.4 & $1.31 \mathrm{E}-03$ \\
\hline 14 & Phil. Fault Luzon 2 & $\mathrm{~A}$ & $8^{*}$ & 22.6 & 7.2 & $4.45 \mathrm{E}-03$ & 6.5 & $8.90 \mathrm{E}-03$ & 5.9 & $1.78 \mathrm{E}-02$ \\
\hline 15 & Phil. Fault Luzon 3 & A & $8^{*}$ & 56.4 & 8.0 & $1.79 \mathrm{E}-03$ & 7.4 & $3.57 \mathrm{E}-03$ & 6.7 & $7.14 \mathrm{E}-03$ \\
\hline 16 & Phil. Fault Luzon 4 & $\mathrm{~A}$ & $8^{*}$ & 59.7 & 8.1 & $1.69 \mathrm{E}-03$ & 7.4 & $3.38 \mathrm{E}-0.3$ & 6.8 & $6.75 \mathrm{E}-03$ \\
\hline 17 & Phil. Fault Luzon 5 & $\mathrm{~A}$ & $8^{*}$ & 74.2 & 8.3 & $1.36 \mathrm{E}-03$ & 7.6 & $2.72 \mathrm{E}-03$ & 7.0 & $5.43 \mathrm{E}-03$ \\
\hline 18 & Phil. Fault Luzon 6 & $\mathrm{~A}$ & $8^{*}$ & 81.1 & 8.3 & $1.24 \mathrm{E}-03$ & 7.7 & $2.48 \mathrm{E}-03$ & 7.1 & $4.97 \mathrm{E}-03$ \\
\hline 19 & Phil. Fault Visayas & $\mathrm{A}$ & $8^{*}$ & 69.3 & 8.2 & $1.45 \mathrm{E}-03$ & 7.6 & $2.91 \mathrm{E}-0.3$ & 6.9 & $5.81 \mathrm{E}-03$ \\
\hline 20 & Phil. Fault mindanao 1 & $\mathrm{~A}$ & $8^{*}$ & 73.6 & 8.3 & $1.37 \mathrm{E}-0.3$ & 7.6 & $2.74 \mathrm{E}-0.3$ & 7.0 & $5.47 \mathrm{E}-0.3$ \\
\hline 21 & Phil. Fault mindanao 2 & $\mathrm{~A}$ & $8^{*}$ & 78.1 & 8.3 & $1.29 \mathrm{E}-03$ & 7.7 & $2.58 \mathrm{E}-03$ & 7.0 & $5.16 \mathrm{E}-03$ \\
\hline 22 & Phil. Fault Bicol segment & $\mathrm{A}$ & $8^{*}$ & 60.9 & 8.1 & $1.65 \mathrm{E}-03$ & 7.4 & $3.30 \mathrm{E}-0.3$ & 6.8 & $6.61 \mathrm{E}-03$ \\
\hline 23 & Phil. Fault Bicol segment & $\bar{A}$ & $8^{*}$ & 35.1 & 7.6 & $2.87 \mathrm{E}-03$ & 6.9 & $5.74 \mathrm{E}-03$ & 6.3 & $1.15 \mathrm{E}-02$ \\
\hline 24 & Phil. Fault Bicol segment & $\mathrm{A}$ & $1^{* *}$ & 25.7 & 7.3 & $4.89 \mathrm{E}-04$ & 6.7 & $9.79 \mathrm{E}-04$ & 6.0 & $1.96 \mathrm{E}-03$ \\
\hline 25 & Phil. Fault Surigao & $\mathrm{A}$ & $1^{* *}$ & 37.6 & 7.6 & $3.35 \mathrm{E}-04$ & 7.0 & $6.70 \mathrm{E}-04$ & 6.4 & $1.34 \mathrm{E}-0.3$ \\
\hline 26 & Phil. Fault Davao segment & $\mathrm{A}$ & $1^{* *}$ & 71.5 & 8.2 & $1.76 \mathrm{E}-04$ & 7.6 & $3.52 \mathrm{E}-04$ & 7.0 & $7.05 \mathrm{~F}-04$ \\
\hline 27 & Cental Mindanao Fault 1 & $\mathrm{~A}$ & $1^{* *}$ & 46.1 & 7.8 & $2.73 \mathrm{E}-04$ & 7.2 & $5.46 \mathrm{E}-04$ & 6.6 & $1.09 \mathrm{E}-0.3$ \\
\hline 28 & Cental Mindanao Fault 2 & $\mathrm{~A}$ & $1^{* *}$ & 36.3 & 7.6 & $3.46 \mathrm{E}-04$ & 7.0 & $6.93 \mathrm{E}-04$ & 6.3 & $1.39 \mathrm{E}-03$ \\
\hline 29 & Cental Mindanao Fault 3 & A & $1^{* *}$ & 47.6 & 7.9 & $2.64 \mathrm{E}-04$ & 7.2 & $5.29 \mathrm{E}-04$ & 6.6 & $1.06 \mathrm{E}-03$ \\
\hline 30 & Lubang Fault & A & $1^{* *}$ & 75.8 & 8.3 & $1.66 \mathrm{E}-04$ & 7.6 & $3.32 \mathrm{E}-04$ & 7.0 & $6.65 \mathrm{E}-04$ \\
\hline 31 & Sibuyan Sea Fault & $\mathrm{A}$ & $1^{* *}$ & 48.1 & 7.9 & $2.62 \mathrm{E}-04$ & 7.2 & $5.24 \mathrm{E}-04$ & 6.6 & $1.05 \mathrm{E}-0.3$ \\
\hline 32 & Tablas Fault 1 & $\mathrm{~A}$ & $1^{* *}$ & 53.7 & 8.0 & $2.34 \overline{\mathrm{E}}-04$ & 7.3 & $4.69 \mathrm{E}-04$ & 6.7 & $9.38 \mathrm{E}-04$ \\
\hline 33 & Tablas Fault 2 & $\mathrm{~A}$ & $1^{* *}$ & 60.5 & 8.1 & $2.08 \mathrm{E}-04$ & 7.4 & $4.16 \mathrm{E}-04$ & 6.8 & $8.32 \mathrm{E}-04$ \\
\hline 34 & Sulu Trench & $\mathrm{A}$ & $1^{* *}$ & 89.1 & 8.4 & $1.41 \mathrm{E}-04$ & 7.8 & $2.82 \mathrm{E}-04$ & 7.2 & $5.65 \mathrm{E}-04$ \\
\hline 35 & East Luzon trench 1 & & $75-85^{\dagger}$ & 69.2 & 8.2 & $1.45 \mathrm{E}-03^{\ddagger}$ & 7.6 & $2.91 \mathrm{E}-03^{\ddagger}$ & 6.9 & $5.82 \mathrm{E}-03^{\ddagger}$ \\
\hline 36 & East Luzon trench 2 & & $75-85^{\dagger}$ & 67.3 & 8.2 & $1.50 \mathrm{E}-03^{\ddagger}$ & 7.5 & $2.99 \mathrm{E}-03^{\ddagger}$ & 6.9 & $5.99 \mathrm{E}-03^{\ddagger}$ \\
\hline 37 & East Luzon trench 3 & & $75-85^{\dagger}$ & 68.4 & 8.2 & $1.47 \mathrm{E}-03^{\ddagger}$ & 7.6 & $2.95 \mathrm{E}-03^{\ddagger}$ & 6.9 & $5.89 \mathrm{E}-03^{\ddagger}$ \\
\hline 38 & East Luzon trench 4 & & $75-85^{\dagger}$ & 74.1 & 8.3 & $1.36 \mathrm{E}-03^{\ddagger}$ & 7.6 & $2.72 \mathrm{E}-03^{\ddagger}$ & 7.0 & $5.44 \mathrm{E}-03^{\ddagger}$ \\
\hline 39 & Philippine Trench 1 & & $80-90^{\dagger}$ & 75.2 & 8.3 & $1.67 \mathrm{E}-03^{\ddagger}$ & 7.6 & $3.35 \mathrm{E}-03^{\ddagger}$ & 7.0 & $6.70 \mathrm{E}-03^{\ddagger}$ \\
\hline 40 & Philippine Trench 2 & & $80-90^{\dagger}$ & 85.8 & 8.4 & $1.47 \mathrm{E}-03^{\ddagger}$ & 7.8 & $2.93 \mathrm{E}-03^{\ddagger}$ & 7.1 & $5.87 \mathrm{E}-03^{\ddagger}$ \\
\hline 41 & Philippine Trench 3 & & $90-100^{\dagger}$ & 58.3 & 8.0 & $2.16 \mathrm{E}-03^{\ddagger}$ & 7.4 & $4.32 \mathrm{E}-03^{\ddagger}$ & 6.8 & $8.64 \mathrm{E}-03^{\ddagger}$ \\
\hline 42 & Philippine Trench 4 & & $90-100^{\dagger}$ & 84.0 & 8.4 & $1.50 \mathrm{E}-03^{\ddagger}$ & 7.7 & $3.00 \mathrm{E}-03^{\ddagger}$ & 7.1 & $5.99 \mathrm{E}-03^{\mp}$ \\
\hline 43 & Manila Trench 1 & $\mathrm{~A}$ & $9^{*}$ & 52.5 & 7.9 & $2.16 \mathrm{E}-03$ & 7.3 & $4.31 \mathrm{E}-03$ & 6.7 & $8.63 \mathrm{E}-03$ \\
\hline 44 & Manila Trench 2 & A & $9^{*}$ & 75.4 & 8.3 & $1.50 \mathrm{E}-03$ & 7.6 & $3.00 \mathrm{E}-03$ & 7.0 & $6.01 \mathrm{E}-03$ \\
\hline 45 & Manila Trench 3 & $\mathrm{~A}$ & $9^{*}$ & 89.3 & 8.4 & $1.27 \mathrm{E}-03$ & 7.8 & $2.54 \mathrm{E}-03$ & 7.2 & $5.08 \mathrm{E}-03$ \\
\hline 46 & Manila Trench 4 & $\mathrm{~A}$ & $9^{*}$ & 76.5 & 8.3 & $1.48 \mathrm{E}-03$ & 7.7 & $2.96 \mathrm{E}-03$ & 7.0 & $5.93 \mathrm{E}-03$ \\
\hline 47 & Manila Trench 5 & $\mathrm{~A}$ & $9^{*}$ & 88.9 & 8.4 & $1.27 \mathrm{E}-03$ & 7.8 & $2.55 \mathrm{E}-03$ & 7.2 & $5.10 \mathrm{E}-03$ \\
\hline 48 & Manila Trench 6 & A & $9^{*}$ & 69.2 & 8.2 & $1.64 \mathrm{E}-03$ & 7.6 & $3.27 \mathrm{E}-03$ & 6.9 & $6.55 \mathrm{E}-03$ \\
\hline 49 & Cotabato Trench 1 & $\mathrm{~A}$ & $1^{* *}$ & 83.8 & 8.4 & $1.50 \mathrm{E}-04$ & 7.7 & $3.00 \mathrm{E}-04$ & 7.1 & $6.01 \mathrm{E}-04$ \\
\hline 50 & Cotabato Trench 2 & $\mathrm{~A}$ & $1^{* *}$ & 36.8 & 7.6 & $3.42 \mathrm{E}-04$ & 7.0 & $6.83 \mathrm{E}-04$ & 6.3 & $1.37 \mathrm{E}-03$ \\
\hline 51 & Cotabato Trench 3 & A & $1^{* *}$ & 39.4 & 7.7 & $3.20 \mathrm{E}-04$ & 7.0 & $6.40 \mathrm{E}-04$ & 6.4 & $1.28 \mathrm{E}-03$ \\
\hline 52 & Negros Trench segment 1 & $\mathrm{~A}$ & $1^{* *}$ & 72.3 & 8.2 & $1.74 \mathrm{E}-04$ & 7.6 & $3.48 \mathrm{E}-04$ & 7.0 & $6.97 \mathrm{E}-04$ \\
\hline 53 & Negros Trench segment 2 & $\mathrm{~A}$ & $1^{* *}$ & 76.7 & 8.3 & $1.64 \mathrm{E}-04$ & 7.7 & $3.28 \mathrm{E}-04$ & 7.0 & $6.57 \mathrm{E}-04$ \\
\hline 54 & Casigura Fault & $\mathrm{A}$ & $1^{* * *}$ & 66.8 & 8.2 & $1.88 \mathrm{E}-04$ & 7.5 & $3.77 \mathrm{E}-04$ & 6.9 & $7.54 \mathrm{E}-04$ \\
\hline 55 & Manila Bay Fracture Zone & $\mathrm{B}$ & $0.1^{\ominus}$ & 29.6 & 7.4 & $4.25 \mathrm{E}-05$ & 6.8 & $8.51 \mathrm{E}-05$ & 6.1 & $1.70 \mathrm{E}-04$ \\
\hline 56 & Iba Fracture Zone & B & $0.1^{\ominus}$ & 23.6 & 7.2 & $5.34 \mathrm{E}-05$ & 6.6 & $1.07 \mathrm{E}-04$ & 5.9 & $2.13 \mathrm{E}-04$ \\
\hline 57 & Mindoro faullt & A & $1^{* *}$ & 56.8 & 8.0 & $2.22 \mathrm{E}-04$ & 7.4 & $4.44 \mathrm{E}-04$ & 6.7 & $8.87 \mathrm{E}-04$ \\
\hline 58 & Bohol fault & $\mathrm{A}$ & $1^{* *}$ & 25.8 & 7.3 & $4.87 \mathrm{E}-04$ & 6.7 & $9.74 \mathrm{E}-04$ & 6.0 & $1.95 \mathrm{E}-03$ \\
\hline 59 & Taal Fracture Zone & $\mathrm{A}$ & $1^{* *}$ & 42.7 & 7.8 & $2.95 \mathrm{E}-04$ & 7.1 & $5.89 \mathrm{E}-04$ & 6.5 & $1.18 \mathrm{E}-03$ \\
\hline \multicolumn{11}{|c|}{$\dagger^{\dagger}$ actual slip rate ${ }^{10)}$} \\
\hline act & tai sing fave & & the & & & $f_{3}$ & & Trenc & & Type A \\
\hline
\end{tabular}


source $k, q_{k}(\gamma)$ is solved from Eq. (10).

$$
\begin{array}{r}
q_{k}(\gamma)=\int_{m_{l k}}^{m_{u k}} \int_{r_{l k}}^{r_{u k}} P(\Gamma>\gamma \mid m, r) f_{M k k}(m) \\
f_{R k}(r) d m d r
\end{array}
$$

where: $f_{M k}(m)$ is the probability density function of magnitude $m$ in source $k, f_{R k}(r)$ is the probability density function of distance $r$ (upper and lower value $\left.=r_{u k}, r_{l k}\right)$ in source $k$, and $P(\Gamma>\gamma \mid m, r)$ is the probability of $(\Gamma>\gamma)$ for given $m$ and $r$. When the uncertainty in attenuation equation of peak ground motion is involved, the attenuation rule $\Gamma=\gamma_{E}(m, r)$ is represented by $\Gamma=U \cdot \gamma_{E}(m, r)$, in which $U$ is the lognormal variate representing attenuation uncertainty with median of 1.0 and coefficient of variation $\delta_{\uparrow}$. Then:

$$
P(\Gamma>\gamma \mid m, r)=P\left(U>\frac{\gamma}{\gamma_{E}(m, r)}\right)
$$

The hayard curve is obtained by calculating $p_{0}$ from Eq. (10) for various values of $\delta_{\gamma}$, allowing one to determine the value $\gamma_{0}\left(p_{0}\right)$ of the intensity parameter corresponding to a specified $p_{0}$.

Let $x$ represent any ground motion parameter being discussed. Assume that it is represented as a function of the earthquake magnitude, $m$, and distance, $r$,

$$
x=\phi(m, r)
$$

The conditional mean of $x$ from $n$ potential earthquake source zones given that $\Gamma>\gamma_{0}\left(p_{0}\right)$ is obtained by,

$$
\bar{x}_{k}\left(p_{0}\right)=\frac{\sum_{k=1}^{n} x_{k}\left(p_{0}\right) \nu_{k} q_{k}\left(\gamma_{0}\right)}{\sum_{k=1}^{n} \nu_{k} q_{k}\left(\gamma_{0}\right)}
$$

where:

$$
\begin{gathered}
x_{k}\left(p_{0}\right)=\frac{1}{q_{k}\left(\gamma_{0}\right)} \int_{m_{l k}}^{m_{u k}} \int_{r_{l k}}^{r_{u k}} \phi(m, r) \\
P\left(U>\frac{\gamma_{0}\left(p_{0}\right)}{\gamma_{E}(m, r)}\right) f_{M k k}(m) f_{R k}(r) d r d m
\end{gathered}
$$

$\nu_{k}=$ annual occurrence rate at source $k$

The conditional mean of the magnitude $\bar{m}_{k}\left(p_{0}\right)$ and that of the distance $\bar{r}_{k}\left(p_{0}\right)$ from $k$ source zones are solved by substituting $m$ and $r$ to Eq. (12) respectively. $\bar{m}_{k}$ and $\bar{r}_{k}$ are the hazardconsistent magnitude and distance respectively.
When the seismic hazard contributions from both the seismogenic zones and fault sources are considered, the annual probability that a random intensity $\Gamma$ will exceed a value $\gamma$ considering $n$ seismogenic zone sources and $m$ fault sources are determined from Eq. (15)

$$
\begin{aligned}
P(\Gamma>\gamma) & =\sum_{k=1}^{n} \int_{n_{l k}}^{m_{u k}} \int_{r_{l k}}^{r_{u k}} \nu_{k} \\
& P\left(U>\frac{\gamma}{\gamma_{E}\left(m_{k}, r_{k}\right)}\right) f_{\Lambda I k}\left(m_{k}\right) f_{R k}\left(r_{k}\right) d r d m \\
& +\sum_{k=1}^{m} \nu_{k}^{F} P\left(U>\frac{\gamma}{\gamma_{E}\left(M_{k}^{F}, R_{k}^{F}\right)}\right)
\end{aligned}
$$

where:

$$
\begin{aligned}
& M_{k}^{F^{*}}=\text { characteristic magnitude from fault } \\
& \nu_{k}^{F^{*}}=\text { annual occurrence frequency of } M_{k}^{F} \\
& R_{k}^{F}=\text { fault distance }
\end{aligned}
$$

A few records in the carthquake database are related to specific faults but it is impossible to accurately eliminate all of them from the database. Although there is a possibility of double counting by adding the contributions of historical events and active faults if events caused by known active faults are not eliminated, but the effect is negligible since eliminating few events does not have much effect to the properties of each seismogenic zone.

\section{(2) Attenuation formula for rock-surface ground motions}

Sugito et al. ${ }^{16)}$ developed a database of modified strong motion records on engineering foundation levels with shear wave velocities of $500 \sim 600$ $\mathrm{m} / \mathrm{sec}$. on the basis of the major Japanese strong motion records. The records obtained on deposit sites were converted into its equivalent free rock level surface motion by the modified equivalent linearization method for the response analysis of layered ground, which is termed as FDEL $\left.{ }^{17}\right)$.

The effective peak ground acceleration $\left(A_{\max }^{e}\right)$ parameter is obtained from the filtered acceleration time histories. According to the definition of $A_{\max }^{e}$ by JMA, the effective peak acceleration is determined from the vector synthesis of three orthogonal components of ground acceleration time histories obtained using the three components of the filtered acceleration time histories. The JMA seismic intensity is scaled in the following relation. 

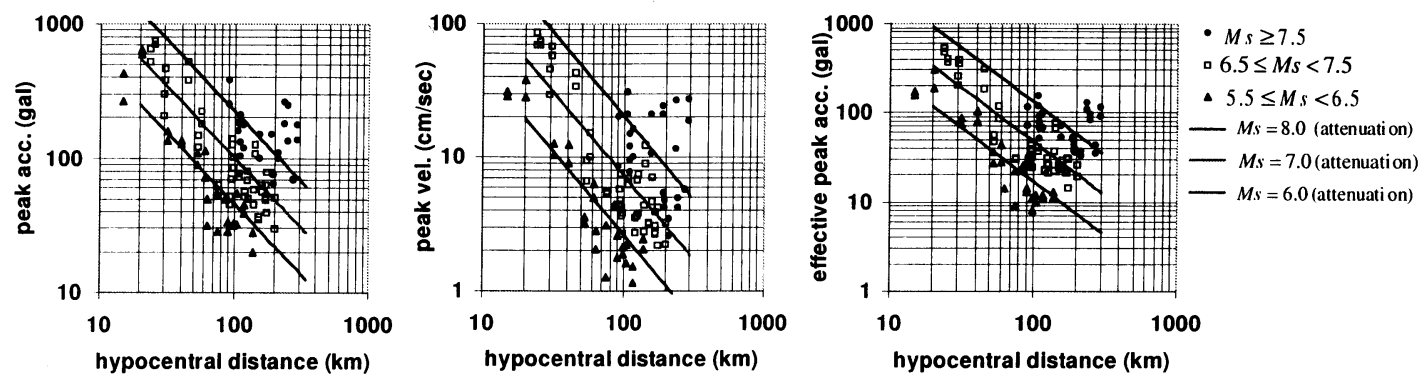

Fig. 4 Attenuation characteristics of peak ground motions with magnitude and hypocentral distance

$$
I_{J M A}=2 \log _{10} A_{\max }^{e}+0.94
$$

Based on this database, a multiple regression analysis was performed to formulate the attenuation equations of peak ground acceleration $\left(A_{\max }\right)$, peak ground velocity $\left(V_{\max }\right)$ and effective peak ground acceleration $\left(A_{\max }^{e}\right)$. The derived attenuation equations for rock-surface peak ground acceleration $\left(A_{\max }^{e}\right)$, peak ground velocity $\left(V_{\text {max }}\right)$ and effective peak ground acceleration $\left(A_{\text {max }}^{e}\right)$ are respectively given in Eqs. (17) to (19).

1. Peak ground acceleration (gal)

$$
\log _{10} A_{\max }=0.346 M_{S}-1.06 \log _{10} R+1.69
$$

2. Peak ground velocity $(\mathrm{cm} / \mathrm{sec}$.)

$$
\log _{10} V_{\max }=0.444 M_{S}-1.24 \log _{10} R+0.24
$$

3. Effective peak ground acceleration (gal)

$$
\log _{10} A_{\text {max }}^{e}=0.446 M_{S}-1.21 \log _{10} R+0.96
$$

where:

$$
\begin{aligned}
& R=\text { hypocentral distance in } \mathrm{km} \\
& M_{S}=\text { surface wave magnitude }
\end{aligned}
$$

The coefficients of variation are $0.44,0.56$ and 0.43 respectively for Eqs. (17) to (19).

The database of strong motion records used in the regression analysis has the minimum hypocentral distance of 20 kilometers, therefore the derived attenuation equations are not applicable to hypocentral distances less than 20 kilometers. Fig. 4 shows the scattergram of the database of 118 components of rock-surface ground motion which are used in the regression analysis to develop the attenuation formula for

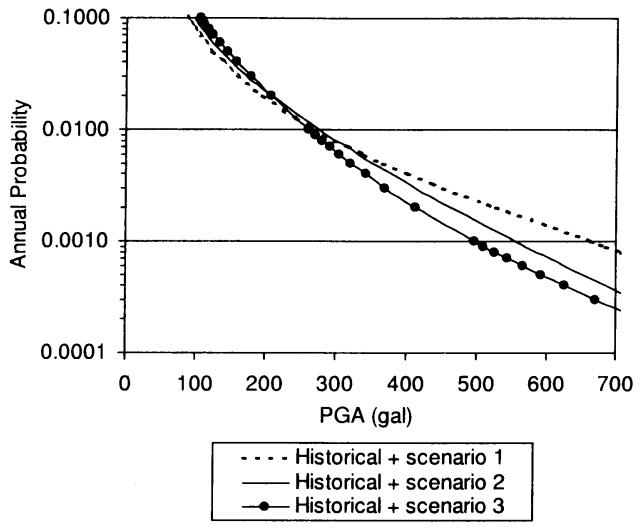

Fig. 5 Hazard comparison for three fault rupture scenarios (Manila)

rock-surface ground motions. The attenuation curves are compared with the database and also shown in Fig. 4.

\section{(3) Results and discussions on hazard anal- ysis in the Philippines}

Probabilistic seismic hazard analysis incorporating the effects of both the active faults and historical earthquakes was done to the whole land area of the country. The average focal depth of historical earthquakes in the country is $21.4 \mathrm{~km}$ for inland events and $27.0 \mathrm{~km}$ for offshore events whereas the average for all the data is $25.1 \mathrm{~km}^{18)}$. A conservative assumption of a $20 \mathrm{~km}$ uniform focal depth of earthquakes was made during the analysis. This assumption was made in order to have a minimum hypocentral distance of 20 kilometers, which is the minimum distance the attenuation equation deemed to be applicable and is close to the average depth of inland events.

Active faults are modeled as lines. The seismic hazards from faults are calculated from the nearest distance to the faults. Seismic hazards from the combined effects of seismogenic source 

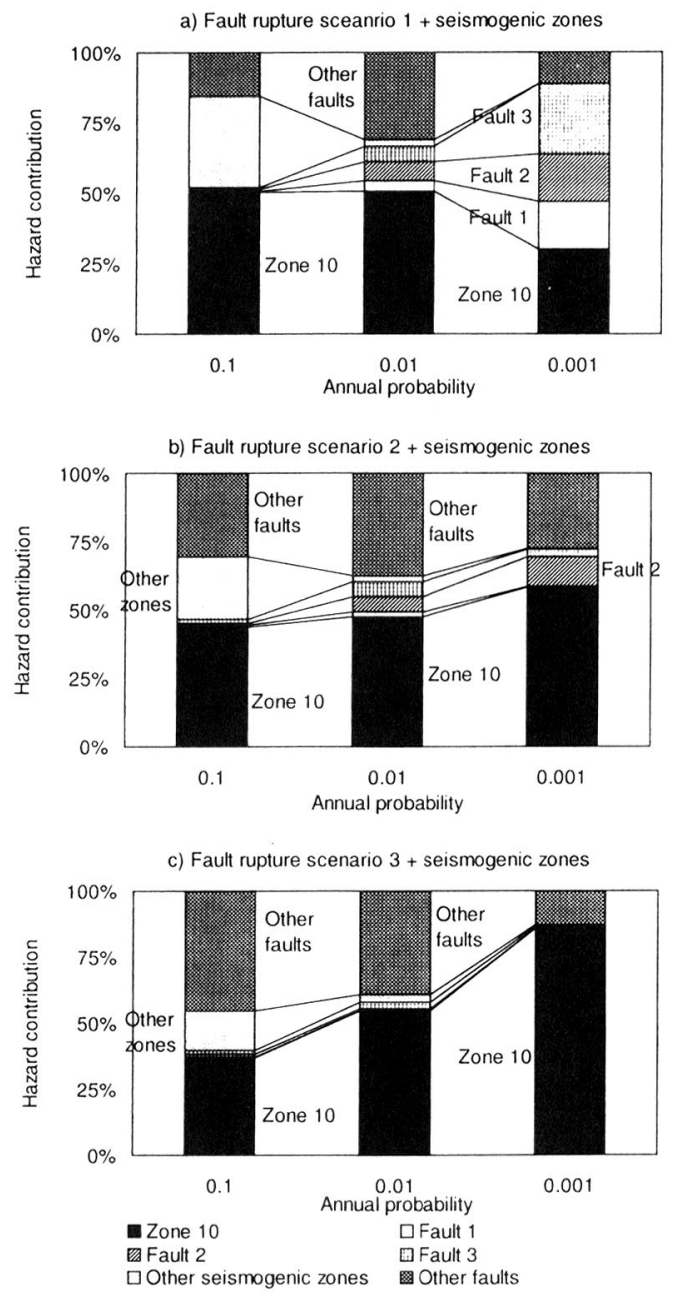

Fig. 6 Hazard contributions for three fault rupture scenarios for Manila based on $A_{\max }$

zones and active faults (i.e, three scenarios) for Manila are given in Fig. 5. Scenario 1 is highest for annual probabilities less than 0.007 , scenario 2 is highest for annual probabilities between 0.007 to 0.02 , whereas for annual probabilities greater than 0.02 , the highest is scenario 3 . At 0.01 annual exceedance probability, the highest hazard is from scenario 2 (276 gal) whereas scenario 1 gives $269 \mathrm{gal}$ and from scenario 3 is $261 \mathrm{gal}$. The PGA hazards of the three scenarios did not differ so much. Fig. 6 gives the source contributions of PGA hazards. The ratios of hazard contributions (seismogenic zones to fault sources) corresponding to $p_{0}=0.01$ are respectively: $53 \%$ to $47 \%$ for scenario $1,50 \%$ to $50 \%$ for scenario 2 , and $57 \%$ to $43 \%$ for scenario 3 . For $p_{0}=0.001$, clearly the highest seismic hazard is from scenario 1 . The reason for the high seismic hazard in scenario 1 is that the hazard contributions from fault sources is much higher than in scenarios 2 and 3 . The ratios of hazard contributions (seismogenic zones to fault sources) for $p_{0}=0.001$ are respectively: $30 \%$ to $70 \%$ for scenario $1,59 \%$ to $41 \%$ for scenario 2 , and $86 \%$ to $14 \%$ for scenario 3 .

Seismic hazard for all the land areas of the Philippines were analyzed. Hazards from fault sources considered three possible scenarios (see Table 3). Annual exceedance probabilities for different levels of ground motion intensities were calculated by combining the contributions from historical earthquakes and the maximum of the three fault rupture scenarios. Fig. 7 shows the rock-surface level peak ground accelerations $\left(A_{\text {max }}\right)$ corresponding to $0.01,0.002$ and 0.001 annual exceedance probabilities. The figures show that maximum hazards are along the major fault lines of the country. Figs. 8 and $\mathbf{9}$ show the rocksurface level peak ground velocity $\left(V_{\max }\right)$, and effective peak ground acceleration $\left(A_{\max }^{e}\right)$ corresponding to 100 -year recurrence period.

Results showed that eastern Philippines has the highest seismic hazard. These places are located on zones with high occurrence rates, which is attributed to the movement of the Philippine plate. Zones 14 and 16 mainly contributed to the maximum seismic hazard for in and around the areas.

The peak ground acceleration map of this study was compared with the result from Molas and Yamazaki ${ }^{3)}$. This study used the attenuation formula for rock-surface ground motions while that of Molas and Yamazaki was based on the average soil condition of observation sites. In both studies, relatively high seismic hazards were observed on eastern Mindanao island. Slight differences of results are on the seismic hazards of Luzon. From Molas and Yamazaki's 100-year recurrence peak ground acceleration map, areas surrounding Baguio City which experienced a destructive earthquake in 1990 , have $A_{\max }$ of 200 gal or more whereas the Central Luzon areas and Metro Manila area have $A_{\text {max }}$ of less than 100 gal. Small clusters of peak ground accelerations up to 600 gal near Baguio City were also found in their study.

In our study, 100-year peak ground accelerations in the range of $150-450$ gal are expected in Central Luzon Island and Metro Manila whereas Baguio city has expected peak acceleration of 450 - 600 gal. Our study showed higher seismic hazards in these areas because of the inclusion of 


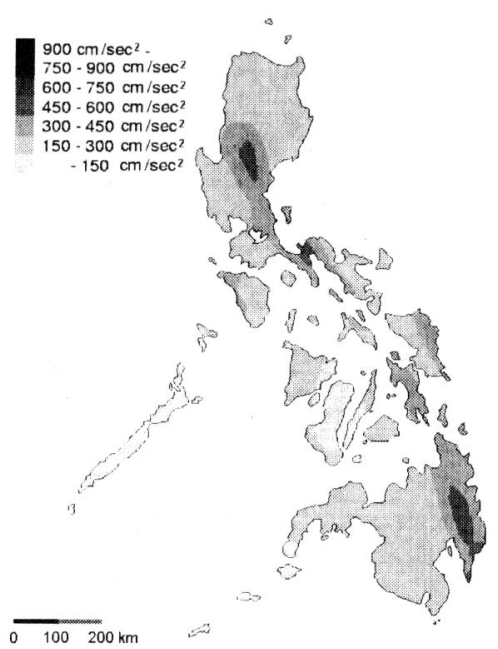

(a) $p_{0}=0.01$

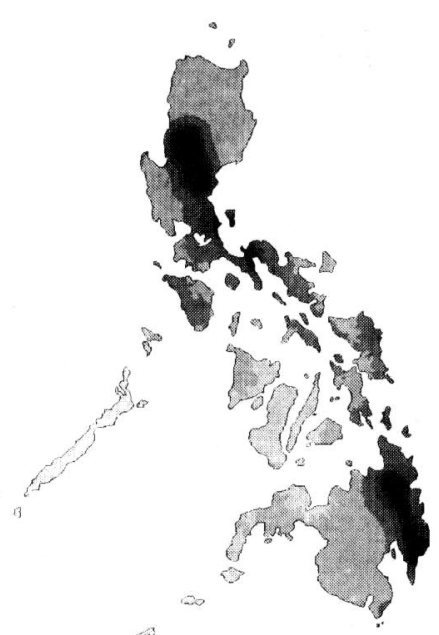

(b) $p_{0}=0.002$

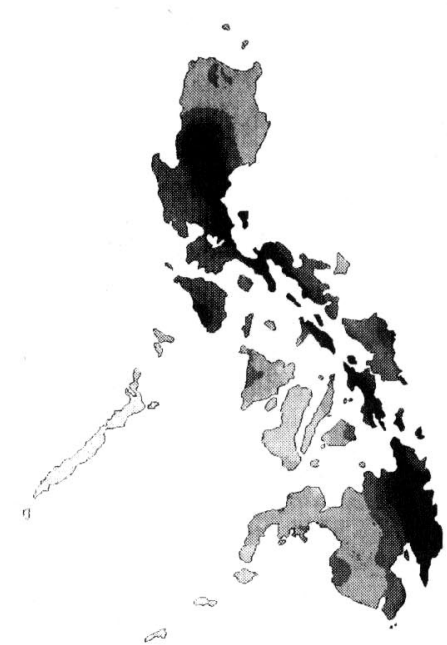

(c) $p_{0}=0.001$

Fig. 7 Peak ground acceleration on rock-surface level

Table 4 Hazard contributions for $p=0.01\left(A_{\max }\right)$

\begin{tabular}{|c|c|c|c|}
\hline \multirow{2}{*}{ City } & \multicolumn{3}{|c|}{ Hazard contributions } \\
\hline Manila & Zone 10 & Fault 2 & Fault 3 \\
\cline { 2 - 4 } & $42 \%$ & $25 \%$ & $17 \%$ \\
\hline Cebu & Zone 18 & Fault 19 & Zone 19 \\
\cline { 2 - 4 } & $57 \%$ & $27 \%$ & $11 \%$ \\
\hline Davao & Zone 23 & Fault 21 & Fault 42 \\
\cline { 2 - 4 } & $42 \%$ & $20 \%$ & $14 \%$ \\
\hline
\end{tabular}

fault sources. Manila for example is located near to Marikina fault (see Fig. 3). Other areas far from active faults, did not show much difference in seismic hazards from both studies.

\section{(4) Hazard-consistent ground motion sim- ulation for Philippine major cities}

Seismic hazards for the three major cities of the country were analyzed. The cities are Manila, Cebu and Davao (see Fig. 2). Seismic hazard contributions from various sources were determined. After analyzing the hazard contributions from various seismogenic zones and fault sources to each city, it is found out that at annual exceedance probability, $p=0.01$, the contribution from each seismogenic zone location dominates the hazard contributions. Table 4 gives the three highest hazard contributions for each city. Manila, Cebu, and Davao (see Fig. 2) are located inside zones 10, 18 and 23 respectively. From this information, it was decided that the hazardconsistent magnitudes and hypocentral distances for Manila, Cebu and Davao were to be determined from their respective seismogenic zone lo-
Table 5 Hazard consistent earthquake parameters with 500-year recurrence period $\left(A_{\max }\right)$

\begin{tabular}{|l|c|c|c|}
\hline \multirow{2}{*}{ City } & \multicolumn{2}{|c|}{ Magnitude } & \multirow{2}{*}{$\begin{array}{c}\text { Hypo-central } \\
\text { distance }(\mathrm{km})\end{array}$} \\
\cline { 2 - 3 } & $\mathrm{M}_{\mathrm{S}}$ & $\mathrm{M}_{\mathrm{J}}$ & 32.2 \\
\hline Manila & 7.1 & 7.0 & 28.8 \\
\hline Cebu & 5.9 & 6.1 & 28.9 \\
\hline Davao & 6.5 & 6.5 & \\
\hline
\end{tabular}

cation. The hazard-consistent magnitudes and hazard-consistent hypocentral distances are respectively shown in Figs. $\mathbf{1 0}$ and 11. From these figures the hazard-consistent magnitudes and hypocentral distance expected within 100 years for the three Philippine major cities were determined. Table 5 gives the hazard-consistent earthquake parameters corresponding to a recurrence period of $T=500$ years.

Manila has comparatively higher hazardconsistent magnitude than Cebu and Davao. The expected magnitude for Manila is $M_{S}=7.1$ $\left(M_{J}=7.0\right)$, whereas for Cebu and Davao are $M_{S}=5.9\left(M_{J}=6.1\right)$ and $M_{S}=6.5\left(M_{J}=6.5\right)$ respectively. The values of hazard-consistent magnitudes are dependent on the properties of the zones where these cities are located. Expected earthquake magnitude in Manila within 100 years is higher than in Cebu and Davao because the bvalue in zone 10 is much smaller than in zones 18 and 23. However, b-value is not the only factor. When zones 18 and 23 were examined, the former was found to have a slightly lower b-value but Cebu has lower expected magnitude when com- 


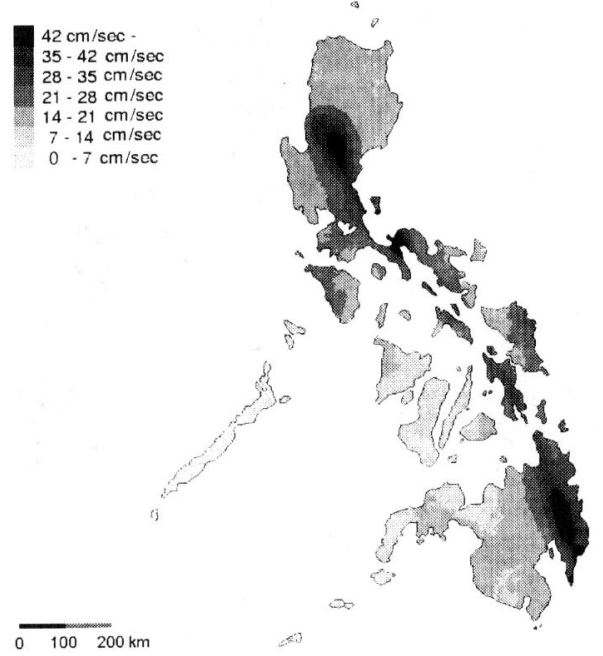

Fig. 8 Peak ground velocity on rock-surface level for 100-vear recurrence

pared to Davao. This is because the maximum magnitude at zone 18 is only 6.7 whereas in zone 23 , the maximum is 7.4. This explains why Davao has higher expected magnitude than Cebu.

For recurrence period of $T=500$ years, the expected hypocentral distance in Manila is 32.2 kilometers whereas in Cebu and Davao are respectively 28.8 and 28.9 kilometers. On the basis of the hazard-consistent magnitude and hypocentral distance, the strong motions corresponding to 500-year recurrence period in Manila, Cebu, and Davao were simulated. Simulation model for rock-surface ground motion developed by Sugito, et al. ${ }^{16)}$ was used. The simulated strong motions for Manila, Cebu and Davao are shown in Fig. 12. Simulated strong motions for Manila, Cebu and Davao showed respective $A_{\max }$ values of 343.5 gal, $96.2 \mathrm{gal}$, and $212.3 \mathrm{gal}, V_{\max }$ values of $24.6 \mathrm{~cm} / \mathrm{sec}, 11.3 \mathrm{~cm} / \mathrm{sec}$, and $14.7 \mathrm{~cm} / \mathrm{sec}$ and $D_{\max }$ values of $7.4 \mathrm{~cm}, 1.7 \mathrm{~cm}$, and $2.3 \mathrm{~cm}$. Response spectra for different percentages of damping are also shown in Fig. 12. The ground motion intensity for Manila is 5.4 on JMA intensity scale. For Cebu and Davao, the intensities are respectively 4.5 and 4.9 on JMA scale. The simulated strong motions are on rock-surface ground motions and did not consider soil conditions.

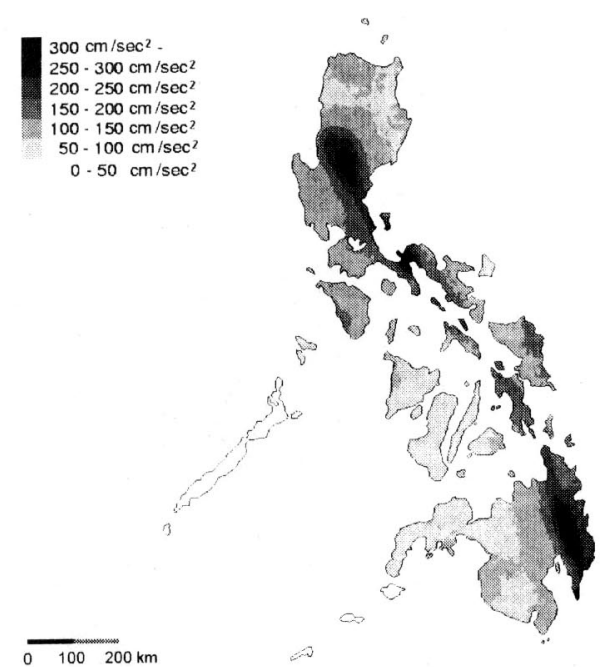

Fig. 9 Effective peak ground acceleration on rock-surface level for 100-year recurrence

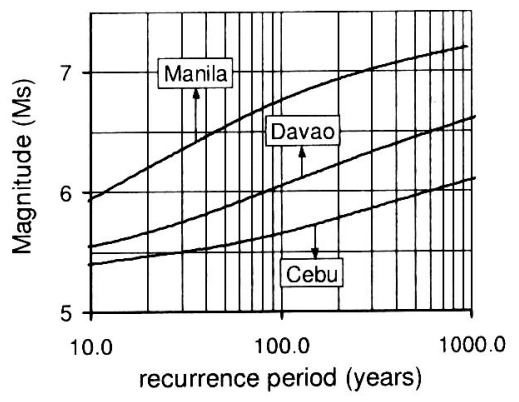

Fig. 10 Hazard-consistent magnitude curve based on $A_{\max }$

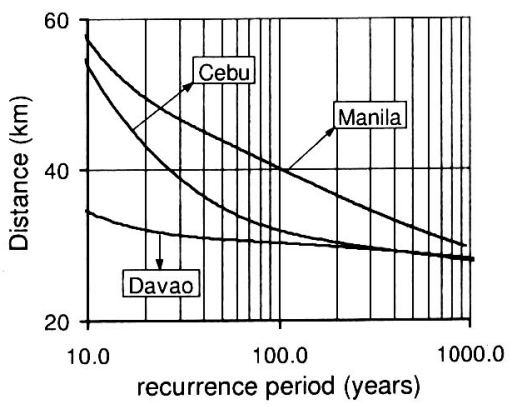

Fig. 11 Hazard-consistent hypocentral distance curve based on $A_{\max }$ 
MAGNITUDE $=7.1 \mathrm{Ms}$

HYPOCENTRAL DIST. $=\mathbf{3 2 . 2} \mathrm{km}$

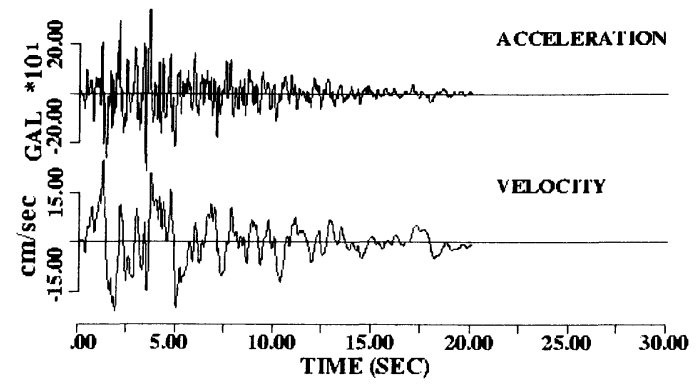

\begin{tabular}{|ll|}
\hline $\operatorname{Amax}=343.5$ gal & Vmax $=24.6 \mathrm{~cm} / \mathrm{sec}$ \\
$\mathrm{A}^{\mathrm{e}} \max =178.0 \mathrm{gal}$ & Intensity $=5.4 \mathrm{JMA}$ \\
\hline
\end{tabular}

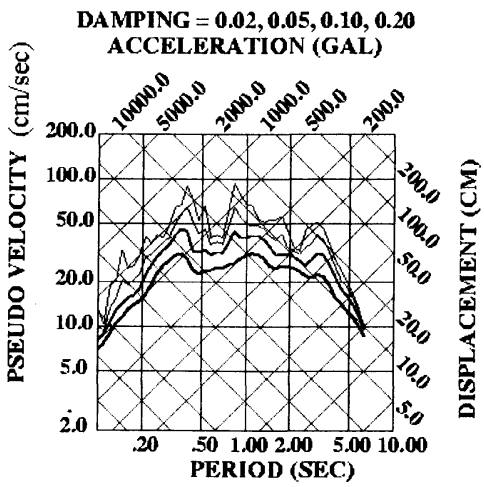

SIMULATED GROUND MOTION TIME HISTORIES FOR CEBU

MAGNITUDE $=5.9 \mathrm{Ms}$

HYPOCENTRAL DIST. $=28.8 \mathrm{~km}$

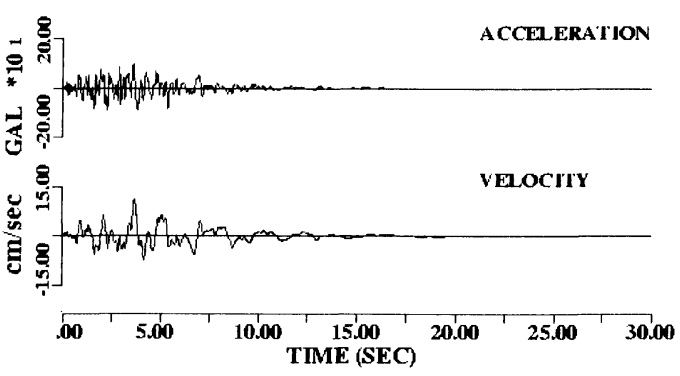

\begin{tabular}{|ll|}
\hline Amax $=96.2$ gal & Vmax $=11.3 \mathrm{~cm} / \mathrm{sec}$ \\
$\mathrm{A}^{\mathrm{e}} \max =60.0 \mathrm{gal}$ & Intensity $=4.5 \mathrm{JMA}$ \\
\hline
\end{tabular}

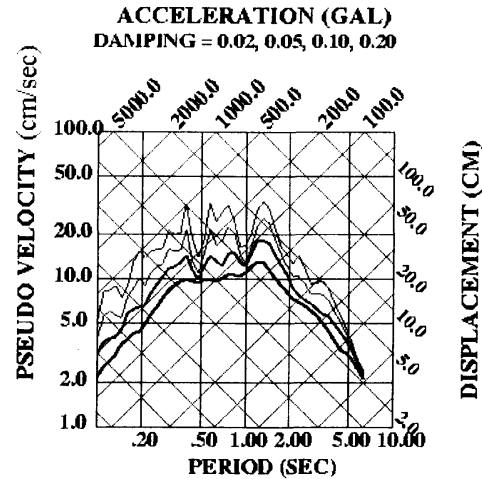

SIMULATED GROUND MOTION TIME HISTORIES FOR DAVAO

MAGNITUDE $=6.5 \mathrm{Ms}$

HYPOCENTRAL DIST. $=28.9 \mathrm{~km}$

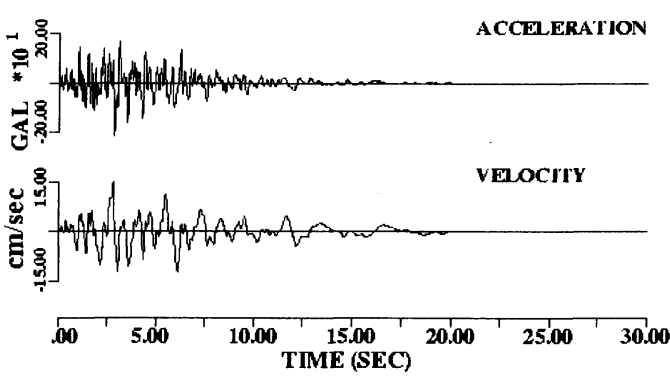

\begin{tabular}{|ll|}
\hline$A \max =212.3 \mathrm{gal}$ & Vmax $=14.7 \mathrm{~cm} / \mathrm{sec}$. \\
$\mathrm{A}^{\mathrm{e}} \max =98.0 \mathrm{gal}$ & Intensity $=4.9 \mathrm{JMA}$ \\
\hline
\end{tabular}

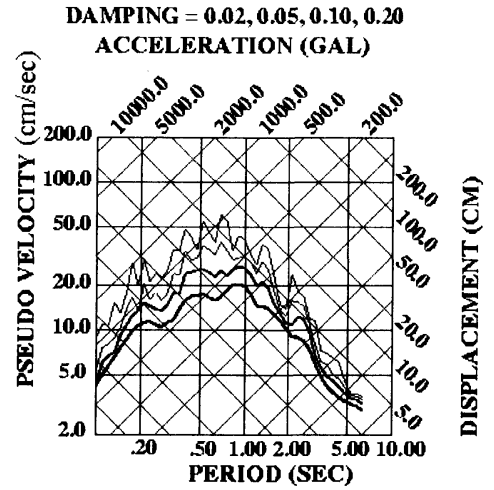

Fig. 12 Example of hazard-consistent ground motions (500-year recurrence) 


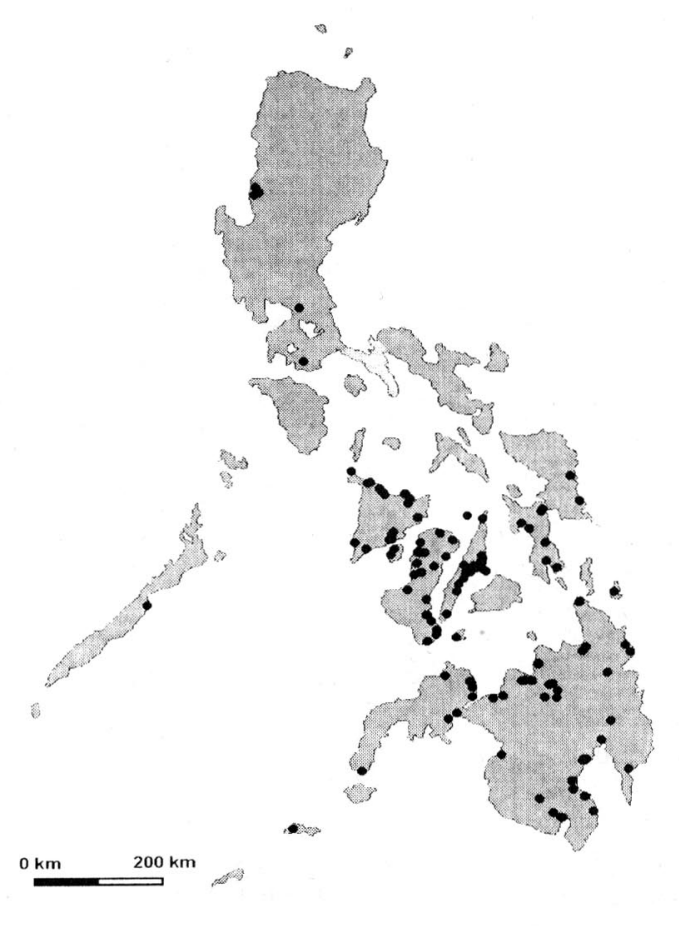

Fig. 13 SP'T investigation sites

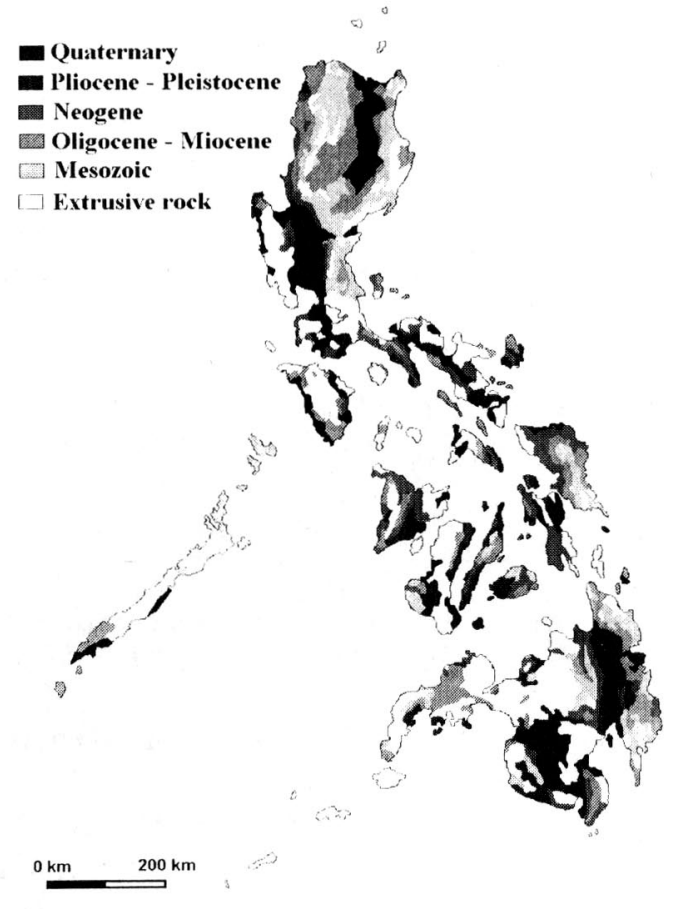

Fig. 14 Geological map of the Philippines

\section{MODELING OF GROUND MO- TION AMPLIFICATION AND MICROZONING OF THE PHILI- PPINES}

\section{(1) Local geology and soil profile dataset of the Philippines}

It has been widely recognized that local geology strongly affects the intensity of ground motions. Su, et al. ${ }^{19)}$ studied the amplifications of ground motion accelerations due to local surface geology from coda waves. They observed that site amplification factor at a station is well correlated with its surficial geology. Ground motion amplification is dependent on the softness of soil deposits as well as the type of soil deposit on the site. Obviously, the softness of soil deposit is well correlated with its geologic age. Therefore, the surface geology is correlated with the ground motion amplifications.

The best way to evaluate the ground motion amplifications would be to perform a response analysis at each individual site. However, this method needs the soil profiles and shear wave velocities for different soil layers in each individual site. These types of data have not been obtained at many sites. Geotechnical investi- gations in the Philippines usually only include the blow-count profiles. The soil testing method that has the most available data in the country is the standard penetration test. Standard penetration test results all over the Philippines were compiled from various geotechnical consultants. Investigated sites are indicated in Fig. 13. The surficial geology of each test site was determined by projecting the site on the geological map of the Philippines shown in Fig. 14. The country's surficial geology is of 6 main types. Namely: Quaternary, Pliocene-Pleistocene, Neogene, Oligocene-Miocene, Mesozoic and Extrusive/Intrusive rocks.

\section{(2) Soil softness index, $S_{n}$}

Furumoto et al. ${ }^{20)}$ developed a simplified method to determine the nonlinear amplification factor for different ground motion intensities by using the blow-count profiles at ground motion observations in Japan. In their method, a soil softness index $\left(S_{n}\right)$ was introduced. From the soil softness index $\left(S_{n}\right)$, the nonlinear ground motion amplification factor $\beta$, can be determined. The ground motion amplification factor, called $\beta$ factor relates the ground motion intensity $Y_{R}$ for rock-surface to $Y_{S}$ for corresponding soil surface 

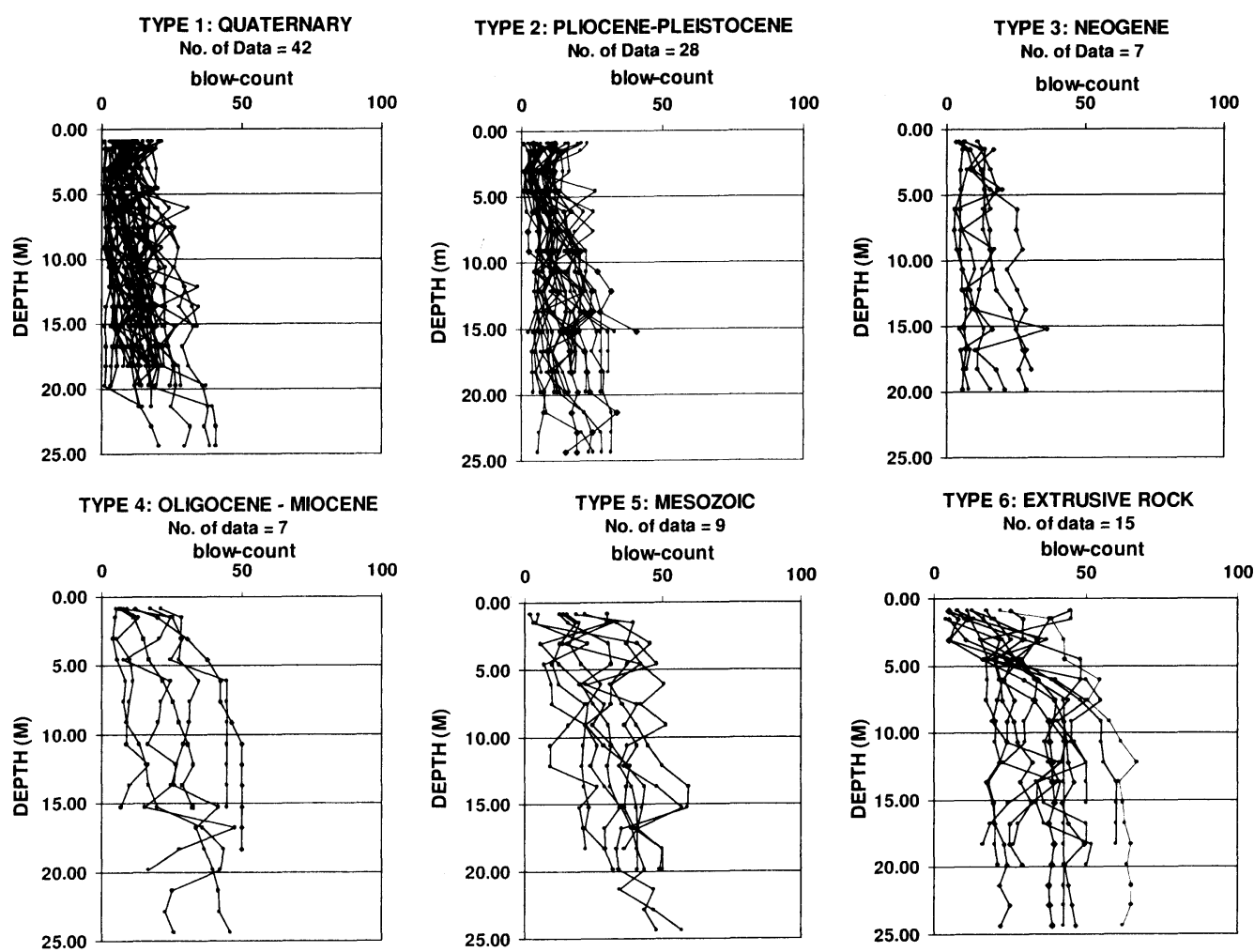

Fig. 15 Blow-count profiles for different surface geology

by the formula $Y_{S}=\beta Y_{R}$. The ground motion amplification factor $\beta$, is a function of the rocksurface ground motion and soil softness index, $S_{n}$, values of site. $S_{n}$ is calculated from Eq. (20).

$$
S_{n}=0.264 \int_{0}^{d_{s}} e^{-0.04 N(x)} e^{-0.14 x} d x-0.885
$$

where:

$N(x)=$ blow-count profile at depth $x$

$x=$ depth in meters

$d_{s}=$ depth of SPT blow-count profile $(\mathrm{m})$

Ground motion amplification factors for peak ground accelerations $\beta_{a}$, peak ground velocity $\beta_{v}$, and effective peak ground accelerations $\beta_{a e}$ are given by Eqs. (21) to (23) listed in Table 6. The soil softness index, $S_{n}$, is non-dimensional parameter with a maximum value of 1.0 corresponding to blow-count $N(x)=0$, for $0 \leq x \leq d_{s}$. $S_{n}$ is fixed at 0 corresponding to blow-count $N(x)=$ 19 , for $0 \leq x \leq d_{s}$. Soft soil deposit is indicated by high $S_{n}$ values and hard soil deposit is indi-
Table 6 Conversion factors for rock to soil surface level ground motions

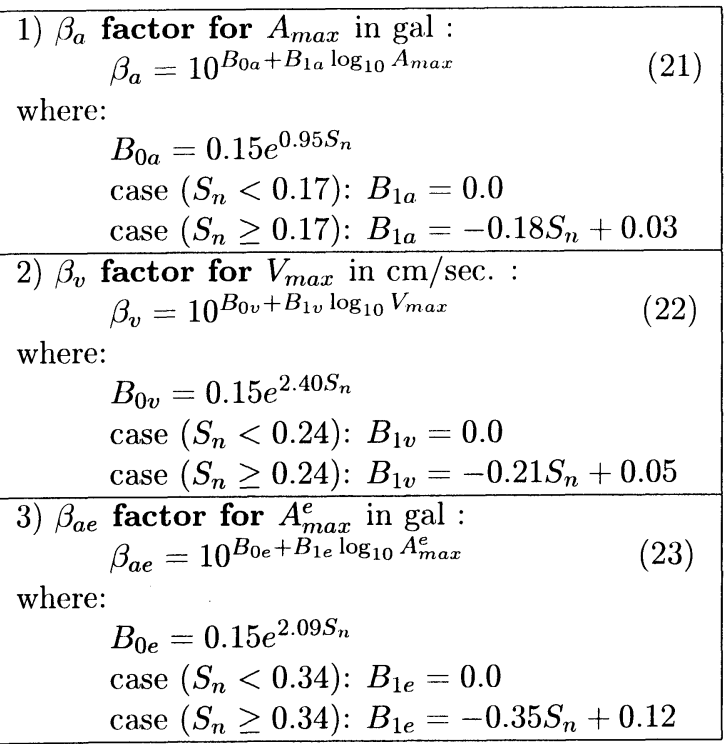

cated by low $S_{n}$ values. 


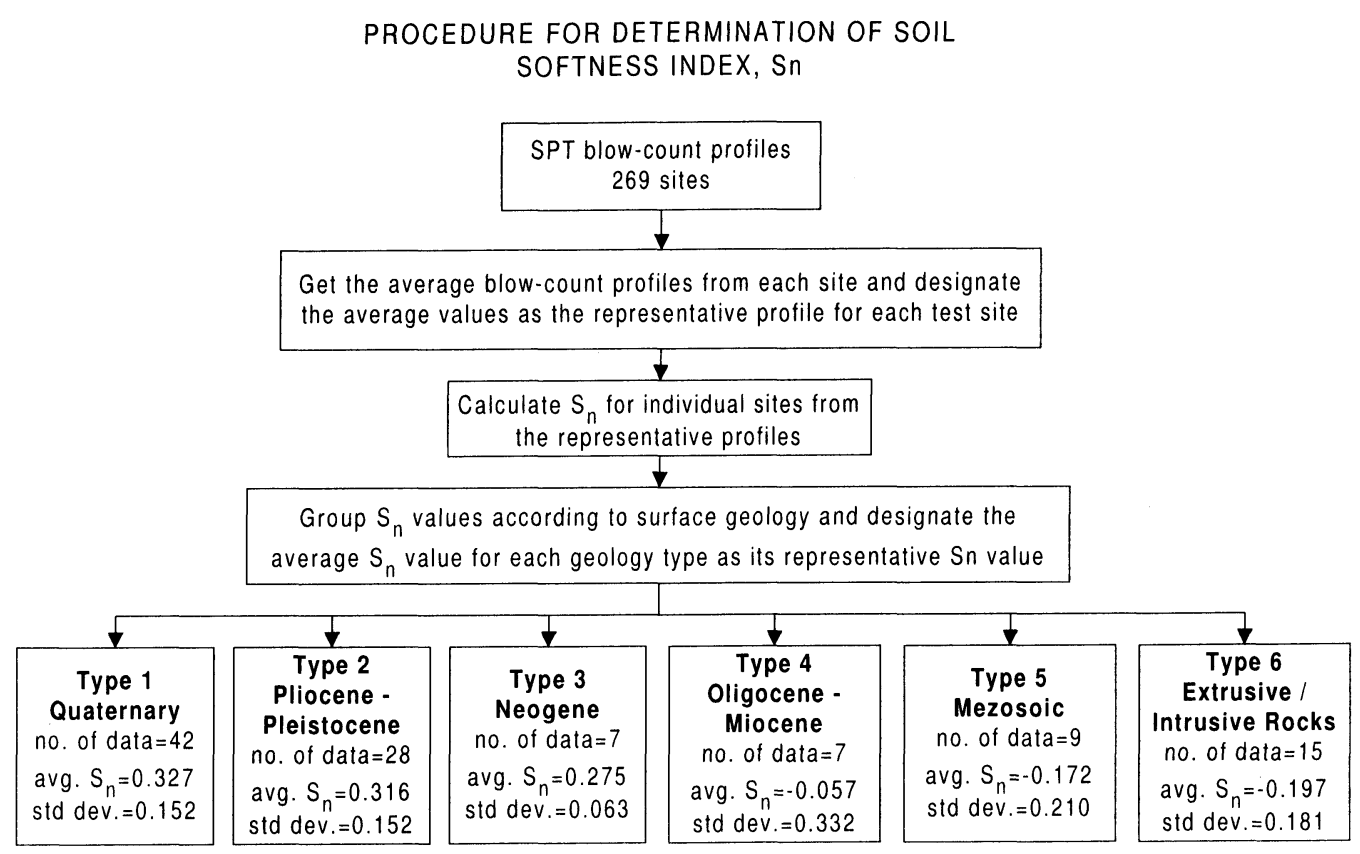

Fig. 16 Procedure for determination of representative soil softness index, $S_{n}$

\section{(3) Ground motion amplification correct- ions by means of the soil softness index, $S_{n}$}

Standard penetration test results from various locations in the Philippines were compiled. SPT procedures in the Philippines ${ }^{21)}$ was found to be identical with the Japanese SPT procedures. The records had values determined from 3 feet $(0.91 \mathrm{~m})$ to 80 feet $(24.39 \mathrm{~m})$. The tests had blow-counts determined for every 5 feet $(1.52$ $\mathrm{m}$ ) of depth interval. The dataset consist of 269 records. Each test site had blow-counts determined from a minimum of one to maximum of ten boreholes.

The sites where the blow-count profiles were obtained are concentrated in the central and southern part of the Philippines. Maximum depth of boreholes varied from site to site. Some sites have boreholes as deep as 80 feet $(24.39 \mathrm{~m})$ and some sites have borehole depths less than 40 feet $(12.19 \mathrm{~m})$. Data that have test hole depth of $15 \mathrm{~m}$ or more were selected for the analysis.

Fig. 15 shows the blow-count profiles for the six surface geology types. Data are concentrated on the first two types; the Quaternary and Pliocene-Pleistocene. The reason for higher discrepancy of the number of data among the six geologic types is that most of the soil investigation

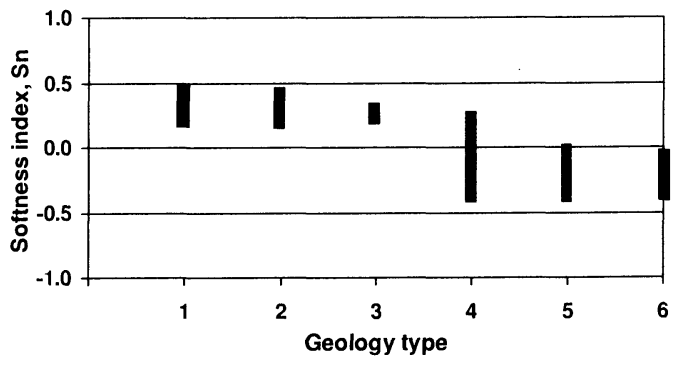

Fig. $17 S_{n}$ values for different geology type

sites are located in the cities where many business establishments had building foundations investigated before construction. Highly urbanized cities in the Philippines are located in plain areas where the surficial geology is of QuaternaryHolocene type (Type 1) or Pleistocene-Pliocene sediments (Type 2).

Soil softness index, $S_{n}$, was determined for every site using the blow-count profiles. Soil softness index values were divided according to the geological age of the soil deposits. The $S_{n}$ values were averaged for sites that belong to the same type of geology and the average $S_{n}$ value in each geology type was designated as the representative soil softness index, $S_{n}$, value. The methodology is given in Fig. 16. Fig. 17 shows the range (i.e., average \pm standard deviation) of $S_{n}$ values 

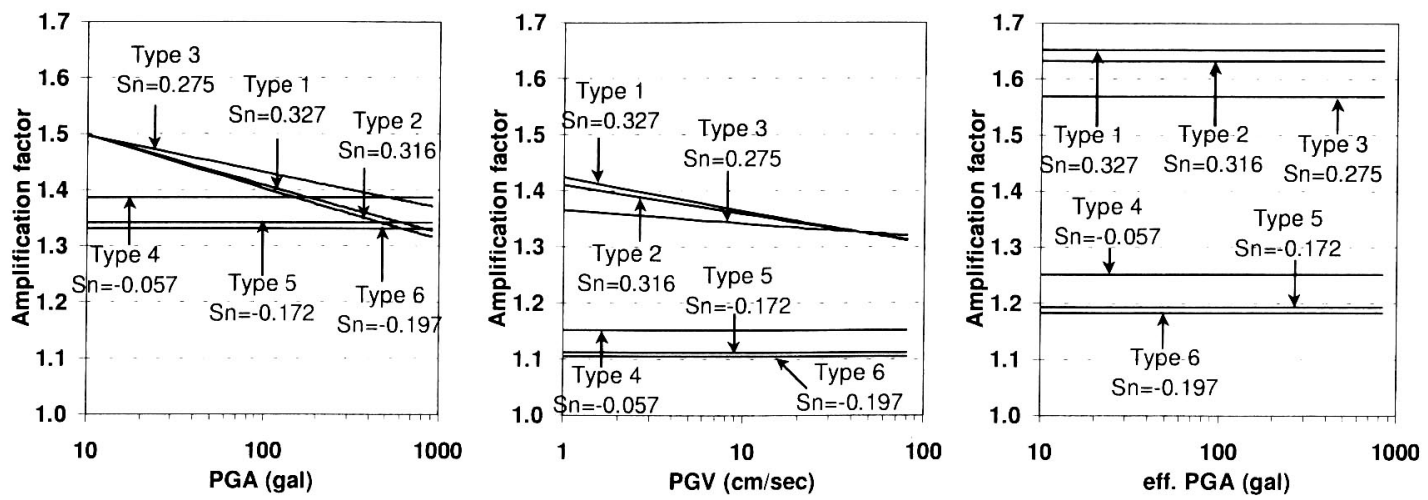

Fig. 18 Amplification factors for $A_{\max }, V_{\max }$ and $A_{\max }^{e}$ using average $S_{n}$ values of each geology type

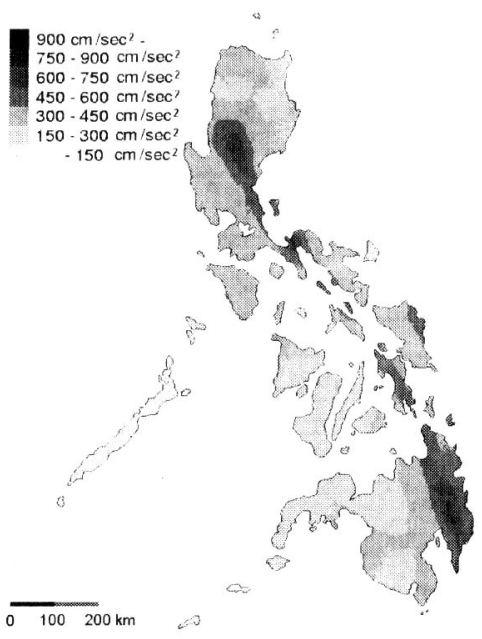

(a) $p_{0}=0.01$

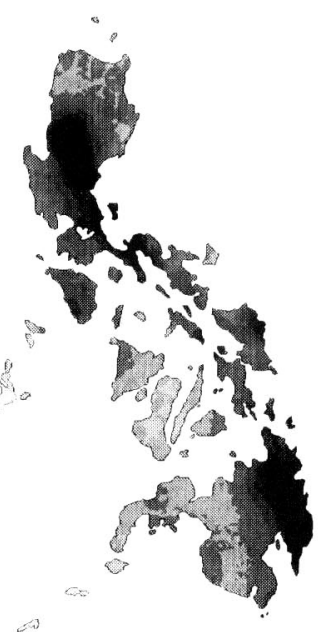

(b) $p_{0}=0.002$

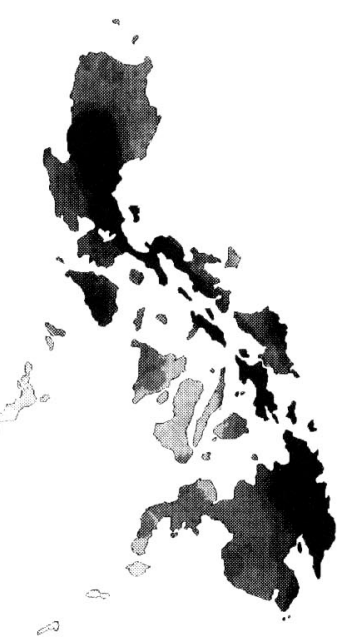

(c) $p_{0}=0.001$

Fig. 19 Peak ground acceleration on soil-surface level

of the 6 geology types.

Based on the representative soil softness index of each geology type, the amplification factors were calculated. Amplification factors for different levels of $A_{\max }, V_{\max }$ and $A_{\max }^{e}$ using average $S_{n}$ values are presented in Fig. 18. For peak accelerations between 10 and 200 gal, the amplification factor is highest in Type 3 followed respectively by Types 1, 2, 4, 5, and 6. However, amplification factors in Types 1 and 2 are lower than that of Type 4 for peak accelerations more than $200 \mathrm{gal}$. The amplification factors for peak ground velocities showed a slightly different characteristics. The highest to lowest amplified geology type is in the order of Types $1,2,3,4,5$, and
6 for peak ground velocities less than $40 \mathrm{~cm} / \mathrm{sec}$. For peak ground velocities more than $40 \mathrm{~cm} / \mathrm{sec}$, Type 3 is slightly higher than Types 1 and 2 . The amplification factors for effective peak ground accelerations are constant for all values of effective peak ground acceleration. These results are only for the representative or average $S_{n}$ values of each geology type. Decreasing values of amplification corrections for $A_{\max }^{e}$ can be observed depending on the actual $S_{n}$ values on a specific site. Highest to lowest amplified type of geology is in the order of Type 1, 2, 3, 4, 5, and 6. In all ground motion parameter types, the amplification factors indicated that ground motions at Quaternary type of geology are amplified more. 


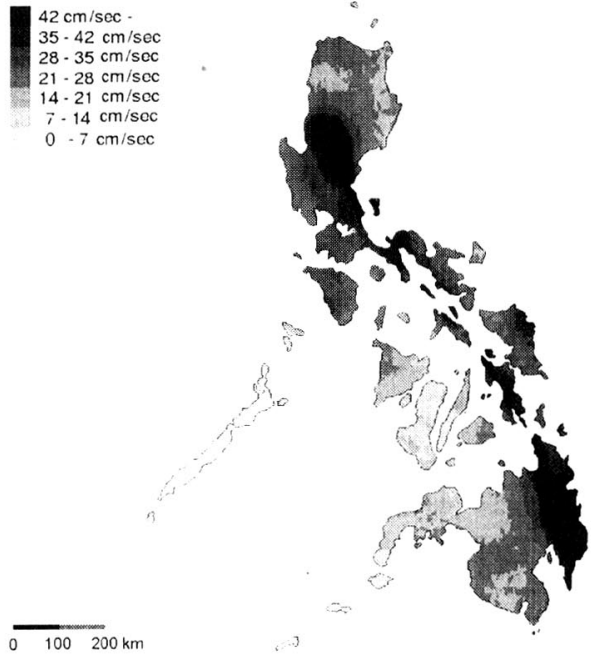

Fig. 20 Peak ground velocity on soil-surface level for 100-vear recurrence

\section{(4) Microzoning based on seismic hazard} analysis

The ground motion amplification corrections determined in the preceding section wore applied to the rock-surface level seismic hayard of the Philippines. Amplification corrections were applied by multiplying the $\beta$ factors by the rock-surface level peak ground acceleration, peak ground velocity and effective peak ground acceleration hazards shown in Figs. 7 to 9. Soilsurface level peak ground accelerations for annual exceedance probabilitics of $0.01,0.002$, and 0.001 are shown in Fig. 19. The increase in seismic hazard after the application of amplification factors is more pronounced for hazards with annual exceedance probability of 0.01 . This is because low peak ground accelerations have higher amplification factors. The soil surface level peak ground acceleration hazard from $p_{0}=0.01$ to $p_{0}=0.002$ shows significant increase as compared to the increase of hazard from $p_{0}=0.002$ to $p_{0}=0.001$. The soil surface level peak ground velocity and effective peak acceleration hazard map with annual exceedance probability of $p_{0}=0.01$ are shown in Figs. 20 to 21. Seismic ground motion intensity hazards increased considerably on areas where the surface geology is Type 1 or Type 2 and the increase is most significant in effective peak ground accelerations.

Both the rock-surface level and soil-surface level ground motions indicated that the seismic

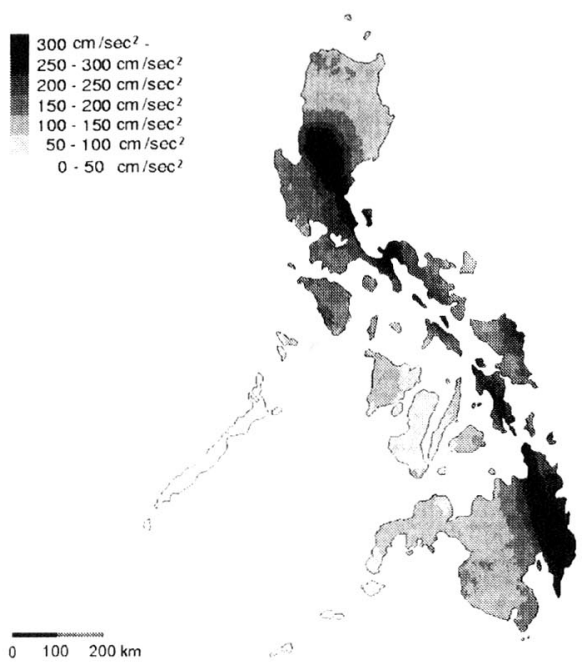

Fig. 21 Effective peak ground acceleration on soilsurface level for 100-year recurrence

hazard of the Philippines is highest on Central Luzon and Eastem Mindanao. These areas are located along the Philippine Fault. However, when ground motion amplification corrections were applied, some areas showed significant increase in ground motion intensities. The most notable increase in seismic hazard are in the city of Manila and central Luzon Island. These areas are located on Quaternary type of geology, which has the highest amplifications for effective peak ground accelerations.

\section{CONCLUDING REMARKS}

Major works and conclusions from this study are the following.

1. Seismic hazard of the Philippines was analyzed on the basis of historical earthquakes and active fault data. Seismic source zoning was done to incorporate the difference of the earthquake occurrence rate of the regions precisely into the hazard analysis. Hazard map for peak ground acceleration, velocity and effective peak acceleration on rocksurface level are presented.

2. The eastern part of the Philippines showed the highest seismic hazard, which is attributed to the movement of the Philippine Trench. Among the three major cities of the country, the capital city of Manila has the highest seismic hazard followed by Davao 
and Cebu.

3. Hazard-consistent earthquake magnitudes and hypocentral distances at seismogenic zone location of the major cities of the Philippines were determined. Ground motion time histories for the major cities of the Philippines were simulated on the basis of the hazard consistent magnitude and hypocentral distance.

4. Representative value for soil softness index, $S_{n}$, was determined for 6 types of local geology on the basis of soil profile datasets. Amplification correction factor is high in young Quaternary sites and minimum at rock sites and older Mesozoic age soil deposits.

5. Microzoning technique was applied to the seismic hazard analysis in the Philippines. The effect of nonlinear ground motion amplification was incorporated for typical six surface geology types using the soil softness index. $S_{n}$. Amplified ground motion intensities showed a significant increase of seismic hazards in the city of Manila and central Luzon island.

\section{REFERENCES}

1) Villaraza, C. M.: A Study on the seismic zoning of the Philippines, Proc. 4th International Conference on Seismic Zonation, Vol. 3 , pp. 511-518, 1991.

2) Su, S. S. : Attenuation of intensity with epicentral distance in the Philippines, Bull. of seismological society of America,Vol. 70, pp. 1287-1291, 1980.

3) Molas, G. L. and Yamazaki, F.: Seismic macrozonation of the Philippines based on seismic hazard analysis, Structural Eng./Earthquake Eng. (JSCE), Vol. II, No.1, pp. 33s-43s , 1994.

4) Torregosa, R., Sugito, M., and Nojima, N.: Assessment of seismic hazard and seismic ground motion amplifications in the Philippines, Third Multi-lateral Workshop on Development of Earthquake and Tsunami Disaster Mitigation Technologies and their Integration for the Asia-Pacific Region, EDM Technical Report, No.11, pp. 131-142, March 2001.

5) Personal communication with Philippine Institute of Volcanology and Seismology (PHIVOLCS) by email.

6) Katayama, T.: An engineering prediction model of acceleration response spectra and its application to seismic hazard mapping, Earthquake eng. struct. dyn., Vol. 10, pp. 149-163, 1982.

7) Rast', B. and Saegesser, R.: On the systematics in defining seismic zones, Proceeding of the 7th World Conference on Earthquake Engineering, Vol. 1, pp.
261-268, 1980.

8) Matsuda, T.: Estimation of size and recurrence period of earthquakes from active faults, Zisin, Vol. 28, pp. 269-283, 1975. (in Japanese)

9) Hayashi, Y. and Abe, K.: A method of Ms determination from JMA data, Zisin, Vol. 37, pp. 429-439, 1984. (in Japanese)

10) Philippine Institute of Volcanology and Seismology (PHIVOLCS) webpage, http://www.phivolcs. dost.gov.ph/

11) Acharya, H. and Aggarwal, Y.: Seismicity and tectonic of the Philippine Islands, Journal of Geophysical Research, Vol. 85, pp. 3239-3250, 1980.

12) Acharya, H., Ferguson, J., and Isaac, V.: Microearthquake surveys in the central and northern Philippines, Bull. of seismological society of America, Vol. 69, pp. 1889-1902, 1979.

13) Hayes, D. and Lewis, S.: A geophysical study of the Manila Trench, Luzon, Philippines, Journal of Geophysical Research, Vol. 89, pp. 9171-9195, 1984.

14) Ishikawa, Y. and Kameda, H.: Hazard-consistent magnitude and distance for extended seismic risk analysis, Proceeding of the 9th World Conference on Earthquake Engineering, Vol. 2, pp. 89-94, 1988.

15) Kameda, H. and Nojima, N.: Simulation of risk consistent earthquake motion, Earthquake eng. struct. dyn., Vol. 16, pp. 1007-1019, 1988.

16) Sugito, M., Furumoto, Y., and Sugivama, T.: Strong motion prediction on rock-surface by superimposed evolutionary spectra, 12th World Conference on Earthquake Engineering, Auckland, New Zealand, January 2000, Paper No. 2111.

17) Sugito, M.: Frequency-dependent equivalent strain for earthquake response analysis of soft ground, Proc. of IS-Tokyo, '95, The First International Conference on Earthquake Geotechnical Engineering, Tokyo, pp. $655-660,1995$.

18) Torregosa, R.: Development of regional seismic hazard analysis technique and its application to engineering designs: A case study for the Philippines and Central Japan, Ph. D. Dissertation, Dept. of Civil Engineering, Gifu University, Gifu, Japan 2002.

19) Su, F., Aki, K., Teng, T., Zeng, Y., Koyanagi, S., and Mayeda, K.: The relation between site amplification factor and surficial geology in Central California, Bull. of seismological society of America, Vol. 82, pp. 580602, 1992.

20) Furumoto, Y., Sugito, M., Nojima, N., and Suzuki, T.: Conversion factor of JMA seismic intensity from base to soil surface with consideration on nonlinear amplification effect, Proceeding of the 34th Japan National Conference on Geotechnical Engineering, Vol. 2, pp. 1949-1950, 1999. (in Japanese)

21) Ramientos, C.: Capistrano N. Ramientos Engineering Consultants Soil Testing Reports, Cebu City, Philippines.

(Received October 26, 2001) 
フィリピンにおける地震危険度解析と地震動マイクロゾーニング

Ribelito F. TORREGOSA, 杉戸真太, 能島暢呂

活断層データと地震発生データを組み合わせたフィリピン全域に㧈ける地震危険度解析，ならびに地震動マイ クロゾーニングを試双た。地震危険度解析では, 地震発生状況に基づいて金国孝 27 のゾーンに区分し, 各ゾー ンの危険度八の奇与率を考慮才るとともに, 活断層については発生地震規模に関して3 種のシナリオを与え, 危 険度への影響について考察した。また，3つの主要都市を対象として各危険度レベルに対灾寸る地震規模と震 源距離の組み合わせを算出し，工学的基盤での時刻歴加速度波形を求めて比較検討した。さらに，地盤資料が

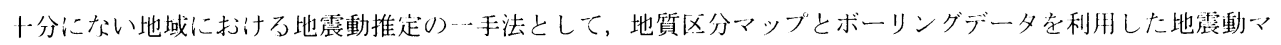

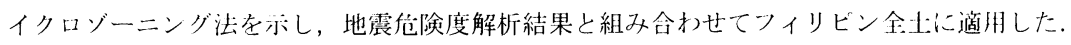

